\title{
POLEMIKE
}

\section{USTREZNEJŠA RABA SLOVENSKIH ZEMLJEPISNIH IMEN}

\author{
AVTORJA
}

\section{dr. Drago Kladnik}

Znanstvenoraziskovalni center Slovenske akademije znanosti in umetnosti, Geografski inštitut Antona Melika, Gosposka ulica 13, SI - 1000 Ljubljana, Slovenija; drago.kladnik@zrc-sazu.si

\section{dr. Drago Perko}

Znanstvenoraziskovalni center Slovenske akademije znanosti in umetnosti, Geografski inštitut Antona Melika, Gosposka ulica 13, SI - 1000 Ljubljana, Slovenija; drago@zrc-sazu.si

DOI: $10.3986 / G V 89205$

UDK: 81'373.21(497.4)

COBISS: 1.02

\section{IZVLEČEK}

\section{Ustreznejša raba slovenskih zemljepisnih imen}

Članek namenjamo bolj zapletenim vidikom in primerom rabe slovenskih zemljepisnih imen, predvsem eksonimov. V prvem delu predstavljamo razširjen in posodobljen pregled ukvarjanja $z$ njimi $v$ Sloveniji. Opozarjamo na velik pomen standardizacije zemljepisnih imen, kakor jo priporočajo mednarodni imenoslovni organi. V nadaljevanju prikazujemo pereča neskladja rabe nekaterih konkretnih zemljepisnih imen, kar je posledica njihove tradicionalno zakoreninjene rabe, nekritičnega povzemanja včasih nedorečenih pravopisnih pravil, pa tudi splošnega nepoznavanja obravnavane tematike. Na koncu predstavljamo poenostavitve pri rabi zemljepisnih imen, kakršne predvideva nastajajoči novi slovenski pravopis.

\section{KLJUČNE BESEDE}

geografija, jezikoslovje, zemljepisna imena, sporna imena, imena držav, eksonimi, endonimi, standardizacija, pravopis, slovenščina, Slovenija

\section{ABSTRACT}

\section{More appropriate use of Slovenian geographical names}

The article is devoted to more complex aspects and examples of the use of Slovenian geographical names, mostly exonyms. In the introductory part we present an extensive and updated overview of dealing with them in Slovenia. We draw attention to the great importance of the standardization of geographical names, as recommended by international toponimic authorities. After that we present the pressing inconsistencies of the use of certain specific geographical names, which is a consequence of their traditionally rooted use, uncritical summation of sometimes inaccurate spelling rules, as well as the general ignorance of the subject matter. In the end, we present simplifications in the use of geographical names, as foreseen by the emerging new Slovenian orthography.

\section{KEY WORDS}

geography, linguistics, geographical names, disputed names, country names, exonyms, endonyms, standardization, orthography, Slovene, Slovenia

Uredništvo je prispevek prejelo 10. oktobra 2017. 


\section{Uvod}

Ustrezno ravnanje z zemljepisnimi imeni je zapletena zadeva, čeprav mnogi mislijo, da jo brez težav obvladujejo. Tudi zato imamo toliko jezikovnih spačkov in v praksi nešteto primerov nesistemske oziroma neusklajene rabe. Čeprav je raba tujih zemljepisnih imen v slovenskem jeziku vse bolj poenotena (Preglednica eksonimov 2014) in pogledi nanjo vse bolj usklajeni (Kladnik 2007b), pa je še vedno mogoče zaznati določene razlike, ki so posledica tradicionalno zakoreninjene, ne najbolj posrečene rabe nekaterih imen ali nekritičnega povzemanja nedorečenih pravopisnih pravil, razlog pa je lahko tudi splošno nepoznavanje obravnavane tematike (Kladnik 2006; Kladnik in Bole 2012; Kladnik s sodelavci 2013).

Poenotenje rabe domačih in tujih zemljepisnih imen, skladno s sprejetimi resolucijami in priporočili Skupine izvedencev Združenih narodov za zemljepisna imena (UNGEGN: United Nations Group of Experts on Geographical Names), ki jo pri nas zastopa Komisija za standardizacijo zemljepisnih imen Vlade Republike Slovenije (KSZI VRS), je med najbolj perečimi vprašanji sodobne jezikovne norme. Mednarodna standardizacijska priporočila za pisanje zemljepisnih imen so pogosto v nasprotju $\mathrm{z}$ jezikoslovno prakso in, kar je povsem nesprejemljivo, v nasprotju z zakonitostmi jezika (Dobrovoljc in Jakop 2012,11). Konsenzualna vprašanja normativistike se ne morejo več razreševati le v ozkih jezikoslovnih krogih, temveč je za vsem sprejemljivo rešitev treba poiskati soglasje v krogu širše strokovne javnosti (Dobrovoljc in Jakop 2011, 8-9).

V prispevku avtorja opozarjava na nekatere odprte dileme rabe za zdaj še neusklajenih oziroma spornih zemljepisnih imen, s čimer želiva prispevati k nadaljnji izboljšavi stanja na tem področju. $Z$ njimi se srečujeva pri pripravi atlasov in zemljevidov, uredniškem delu in sooblikovanju pravil v nastajajočem novem slovenskem pravopisu. O marsičem sva skupaj, posamič ali skupaj s sodelavci že poročala in polemizirala $\mathrm{v}$ številnih člankih in monografijah, na tem mestu pa želiva geografski srenji na jedrnat način predstaviti nekatere odprte dileme in pereča neskladja.

Pričakovati je, da bo obravnavano gradivo tudi dobra iztočnica za potrebno standardizacijo glavnine še vedno nestandardiziranih slovenskih zemljepisnih imen, predvsem slovenskih eksonimov. Glede na to, da sva oba tesno vpeta v delo Pravopisne komisije pri pripravi novega slovenskega pravopisa, upava, da se bodo vsaj najbolj nedvoumne nakazane rešitve znašle tudi v nastajajočem pravopisu, ki naj bi izšel na začetku dvajsetih let tega stoletja. Navedene naj bi bile kot ponazorila k posameznim pravilom in v njegovem slovarskem delu.

\section{Dosedanja obravnava}

O zemljepisnih imenih je bilo v slovenski geografski literaturi napisanega že precej. Naj za začetek omenimo analizo imenskega korpusa iz aktualnega slovenskega pravopisa iz leta 2001, v Geografskem vestniku objavljeno pred dobrim desetletjem (Kladnik 2005a), ki je pričujočemu zapisu še najbolj sorodna. V nadaljevanju podajava izpopolnjen in posodobljen pregled. Značilen življenjski cikel zemljepisnih imen je podrobneje predstavil Peršolja (2003) in ob tem predlagal oblikovanje zbirke tistih slovenskih zemljepisnih imen, ki niso zajeta v Registru zemljepisnih imen (REZI).

V svetovnem merilu velja izpostaviti monografijo izraelskega toponomastika Naftalija Kadmona, v kateri celovito in raznovrstno obravnava zemljepisna imena (Kadmon 2000). Kot geograf seveda izpostavlja prostorske in praktične vidike njihove rabe, pri čemer s svojim izvirnim pristopom na zanimiv način razkriva dramatičnost, ki lahko spremlja njihovo izpostavljeno vlogo, značilno za polpretekla in sodobna dogajanja na globalni ravni. Preučevanje zemljepisnih imen in ravnanje z njimi sta na svetovni ravni zelo dobro organizirana, saj sta tesno vpeta v delovanje Organizacije združenih narodov (OZN). UNGEGN, ena od sedmih izvedenskih skupin Ekonomskega in gospodarskega sveta OZN (United Nations Economic and Social Council, kratko ECOSOC), je bila uradno ustanovljena leta 1964 (Kladnik 2007b, 92). Ko je Slovenija leta 1992 vstopila v OZN, se je zavezala, da bo spoštovala in upoštevala 
vse resolucije OZN, povezane z zemljepisnimi imeni, zato je bilo pripravljeno delovno gradivo, ki toponimske resolucije skupaj z njihovo vsebino podrobneje predstavlja tudi v slovenskem jeziku (Radovan in Orožen Adamič 1999). V Sloveniji skrbi za obravnavo in standardizacijo zemljepisnih imen KSZI VRS, ustanovljen leta 1986 (Perko 1995; Kladnik 2007b, 109-113). Sestavljajo ga geografi, jezikoslovci, geodeti in predstavniki državnih ustanov.

Zgoščen pregled ukvarjanja slovenskih geografov z zemljepisnimi imeni podaja Kladnik (2012), daljša zapisa o tem, kjer je poleg vloge geografov predstavljena tudi vloga naših jezikoslovcev, pa sta tudi sestavna dela do zdaj edinih slovenskih geografskih disertacij, v katerih avtorja predstavljata rezultate podrobnih raziskav zemljepisnih imen (Kladnik 2006; Geršič 2016b). Prvi je članek o zemljepisnih imenih oziroma pisavi krajevnih imen objavil najpomembnejši slovenski geograf Anton Melik (1928). Mnogo pozneje so se slovenski geografi v stremljenju po uveljavitvi svojih pogledov na pravopisna pravila tesneje organizirali in podali konkretne predloge (Gams 1972; Gams 1984), ki pa takrat še niso naleteli na odobravanje jezikoslovcev, zato v aktualnem pravopisu iz leta 2001 niso bili upoštevani. Ker je ob njegovi pripravi prišlo do mnogih stvarnih napak, nedoslednosti in pomanjkljivosti (Lenarčič 2002a; 2002b; 2004; Kladnik 2005a), ki so tudi posledica nepoznavanja geografske stvarnosti doma in po svetu, pa tudi, ker se je v okviru KZSI VRS sodelovanje med geografi in jezikoslovci okrepilo, zaupanje pa poglobilo, smo pri pripravi novega slovenskega pravopisa geografi aktivno vključeni v delo Pravopisne komisije.

Med stremljenji jezikoslovcev velja $\mathrm{z}$ vidika zanimivosti za geografe najprej izpostaviti zgodovino pravopisnih pravil za slovenščino (Dobrovoljc 2004), pri čemer so skozi časovni prerez obravnavani tudi poglavitni pravopisni problemi. Sicer je temeljna načela pri pisanju slovenskih pravopisnih imen prva podrobneje predstavila jezikoslovka Alenka Šivic-Dular (1989). Pozneje je skupaj s sodelavkama v okviru KSZI VRS pripravila za domačo in mednarodno javnost zanimiv priročnik o pravopisni ustreznosti zapisa lastnoimenskega gradiva v REZI-ju in Registru prostorskih enot (Furlan, Gložančev in Šivic-Dular 2000). Med pomembnimi novejšimi dosežki slovenskih jezikoslovcev nikakor ne smemo zaobiti etimološkega slovarja slovenskih zemljepisnih imen (Snoj 2009), ki nas podrobno seznanja $\mathrm{z}$ nastankom in izvorom marsikaterega našega zemljepisnega imena. Pri pripravah za posodobitev slovenskega pravopisa so doslej izšle tri monografije (Dobrovoljc in Jakop 2011; 2012; Dobrovoljc in Lengar Vrhovnik 2015), v katerih je tudi za geografe, ki se želijo pobliže seznaniti z odprtimi dilemami slovenskega pravopisja, nekaj zanimivih prispevkov. Čeprav jih je večina izpod peresa jezikoslovcev (Bizjak 2012; Dobrovoljc 2012a; 2012b; Jakop 2012; Jemec Tomazin 2012; Horvat 2015; Torkar 2015), so v njih tudi članki geografov (Kladnik in Perko 2015a; 2015b) in izkušenega urednika (Pogačnik 2012). Slednji je že desetletje prej objavil prispevek o glasovnem domačenju lastnih imen iz nelatiničnih pisav (Pogačnik 2003), pomemben za slovenjenje tujih zemljepisnih imen.

Razpon sodobnega poglobljenega ukvarjanja z zemljepisnimi imeni na Slovenskem je širok, saj sega vse od mikrotoponimov do imen držav in najpomembnejših odvisnih ozemelj, pri čemer igrajo posebno vlogo eksonimi. Med mikrotoponime običajno uvrščamo hišna in ledinska imena, mednje pa bi glede na manjšo razsežnost lahko uvrstili tudi ulična imena.

Politično motivirane vzgibe spreminjanja uličnih imen v Ljubljani sta preučila Geršič in Kladnik (2014). Sodobno metodologijo raziskovanja hišnih in ledinskih imen so razvili v okviru meddržavnega projekta FLU-LED (Klinar s sodelavci 2012), o čemer je izšlo še nekaj člankov (Klinar in Geršič 2014; Geršič in Kladnik 2016; Škofic 2017). Ob tem velja posebej izpostaviti, da so bila leta 2010 slovenska hišna in ledinska imena na avstrijskem Koroškem uvrščena na UNESCO-v seznam nesnovne dediščine v Avstriji (Piko-Rustia 2010), kar je z vidika tamkajšnje slovenske manjšine neprecenljiva vrednota. Hišna imena se sistematično raziskujejo na Gorenjskem, o čemer je izšla vrsta knjižic s skupnim naslovom Kako se pri vas reče? (Klinar 2013). O njih je bil objavljen zapis tudi v slovenski geografski periodiki (Klinar in Geršič 2014), medtem ko je bilo že prej opravljenih več jezikoslovnih raziskav (na primer Škofic 1998; Zorko 2004), med njimi tudi v zamejski Ovčji vasi v Kanalski dolini (Šekli 2005). Z ledinskimi imeni in njihovo sporočilnostjo se ukvarjajo predvsem jezikoslovci (na primer Šekli 2007) in 
krajinski arhitekti (na primer Penko Seidl 2008; 2011). Med geografi velja izpostaviti članka o ledinskih imenih na kmetijskih terasah (Geršič 2016a) ter na območjih Zahodnih Karavank in zahodnih Kamniško-Savinjskih Alp (Geršič in Zorn 2016), pri čemer je bil posebej izpostavljen odtis naravnih nesreč.

Tudi v svetovnem merilu je pomembna novost sistematična raziskava pokrajinskih imen ali horonimov (Geršič 2016b; 2017). S tem prehajamo k obravnavi večjih ozemeljskih enot, med katerimi ima pri nas razmeroma dolgo tradicijo preučevanje imen držav in najpomembnejših odvisnih ozemelj, o čemer je v slovenski geografski periodiki prvi članek izšel že v osemdesetih letih prejšnjega stoletja (Lovrenčak 1987). Razhajanja med pravopisom in standardiziranimi imeni držav ter odvisnih ozemelj po standardu SIST ISO 3166 iz leta 1996 obravnavata dva prispevka (Perko 1996a; 1996b), medtem ko so na neujemanja med imeni v Slovenskem pravopisu (2001) in seznamu SIST ISO 3166 opozorili tudi jezikoslovci (Furlan 2003) ter ob tem pripravili predloge za nadaljnje delo.

Tako je v okviru KSZI VRS začela delovati Podkomisija za imena držav, sestavljena iz geografov in jezikoslovcev. Ta je $\mathrm{v}$ dveh letih rednih posvetovanj na podlagi konsenzualnega odločanja pripravila izhodiščni predlog s poenotenimi imeni držav, katerega rešitve naj bi bile uporabljene tako v novem slovenskem pravopisu kot slovenskem standardu SIST ISO 3166. O dosežkih podkomisije in njenih utemeljitvah v primeru spornih oziroma problematičnih imen je izšlo več člankov (Kladnik in Perko 2007; 2015a; 2015b), krona prizadevanj pa je monografija Slovenska imena držav (Kladnik in Perko 2013b), v kateri so za posamezne države med drugim podani standardizirano slovensko kratko ime, slovensko uradno kratko ime in slovensko uradno polno ime.

V zadnjih letih se je pri nas še posebej razmahnila obravnava eksonimov. O njihovi ustrezni rabi je tudi v svetovnem merilu več jedrnatih zapisov (na primer Jordan 2000), o njih je izšla posebna monografija (Jordan, Orožen Adamič in Woodman 2007), v Acti geographici Slovenici pa pred kratkim posebna izdaja (Perko, Jordan in Komac 2017). Med slovenskimi geografi je prvi članek o načelih za pisanje tujih zemljepisnih imen pripravil Jakob Medved (1969), le nekaj let pozneje pa je o tem poglobljen zapis pripravil jezikoslovec Janko Moder (1972) in ga objavil v besedilnem delu prvega res zajetnega atlasa sveta v slovenščini. Za razumevanje zgodnje faze nastajanja slovenskih eksonimov je zelo pomemben zapis o zemljepisnih imenih v slovenskem časopisju do srede 19. stoletja (Orel 2003), medtem ko njihovo rabo v najstarejših slovenskih atlasih sveta pojasnjujejo dva članka (Kladnik 2005a; 2007c) in monografija (Kladnik 2007a). Najbolj celovito obravnavo podomačevanja tujih zemljepisnih imen v slovenščino ponuja druga monografija v zbirki Georitem (Kladnik 2007b). Omeniti velja še teoretska članka o pomenski razmejitvi med pojmoma endonim in eksonim (Kladnik 2009a; 2009b), članek o življenjskem ciklu slovenskih eksonimov in njihovem poznavanju v strokovni javnosti (Kladnik in Bole 2012), zapis o primerjavi slovenskih in hrvaških eksonimov (Kladnik s sodelavci 2017) ter prispevek o slovenskih eksonimih v Severni Ameriki (Perko in Kladnik 2017). Obenem s poglobljeno obravnavo slovenskih eksonimov so bili pripravljeni tudi njihovi spletno dostopni seznami, ki jim je uspelo pridobiti značaj referenčnih virov. Prvi seznam je že s preloma iz 20. v21. stoletje (Kladnik 2001), mnogo popolnejši pa je nastal na podlagi aplikativnega projekta Slovenski eksonimi: metodologija, standardizacija, GIS, potekajočega v letih 2008-2011, katerega rezultat je tudi znanstvena monografija (Kladnik s sodelavci 2013). Seznam je dostopen v rubriki Zbirke na spletni strani Geografskega inštituta Antona Melika ZRC SAZU (Preglednica eksonimov 2014), z naslovom Slovar slovenskih eksonimov (Kladnik in Perko 2013a) pa je vključen tudi v spletno zbirko slovarjev Termania na spletnem mestu http://www.termania.net/. Zanj je pripravljeno tudi pregledno pojasnjevalno besedilo (Kladnik in Perko 2014). O slovenskih dosežkih pri pripravi zbirke eksonimov smo poročali tudi na srečanju UNGEGN-ove Delovne skupine za eksonime (Working Group on Exonyms) (Kladnik in Geršič 2014). V sklop obravnave tujih zemljepisnih imen v slovenskem jeziku lahko uvrstimo tudi informativen zapis o številu in imenih svetovnih oceanov (Perko 2006).

V zvezi s slovenskimi eksonimi velja izpostaviti tudi zapis o rabi angleških zemljepisnih imen v slovenščini (Šabec 2003). Njegovo pomensko nasprotje sta članka, namenjena obravnavi slovenskih zemljepisnih imen v tujih jezikih (Berk 2001; Geršič in Kladnik 2015). 
Mnoge spremembe zemljepisnih imen so politično motivirane in tudi o tem smo slovenski geografi objavili nekaj člankov, tako za spremembe krajevnih imen (Urbanc in Gabrovec 2005) kot uličnih imen (Geršič in Kladnik 2014). S tem prehajamo na področje spornih zemljepisnih imen, ki smo jih zaradi za Slovence spornega novodobnega hrvaškega preimenovanja Piranskega zaliva v Savudrijsko valo oziroma Savudrijski zaljev še posebej skrbno in temeljito obdelali. O tem smo pripravili več člankov (na primer Kladnik in Pipan 2008; 2011) ter obsežno, slikovno bogato dokumentirano monografijo (Kladnik, Pipan in Gašperič 2014), kjer so podrobno obdelani tudi glavni svetovni imenoslovni spori, denimo spor med Japonci in Korejci glede mednarodne rabe imena za Japonsko/Vzhodno morje (Kladnik, Pipan in Gašperič 2014, 20-28).

Ena glavnih nalog KSZI VRS v slovenskem merilu in UNGEGN-a v svetovnem je standardizacija zemljepisnih imen, ki omogoča njihovo poenoteno rabo na nacionalni in mednarodni ravni. Pri nas je prvi članek o teh prizadevanjih izšel v Geodetskem vestniku (Rotar 1991). V Sloveniji smo najprej standardizirali imena naselij, za kar je bil izdelan obsežen elaborat (Gabrovec in Perko 1997). Pozneje so bila standardizirana vsa imena na ozemlju Republike Slovenije z zemljevida v merilu $1: 1.000 .000$ (Perko 2001), nekaj let zatem pa še z državne pregledne karte v merilu $1: 250.000$ (skupaj dobrih 4000 imen), ki jo je posebej za ta namen izdala Geodetska uprava Republike Slovenije (Furlan s sodelavci 2008). Že leta 1996 so bila standardizirana imena držav, vendar je ta standardizacija leta 2007 doživela temeljito prenovo.

\section{Metodologija}

Za kvantifikacijo obravnavane tematike smo dodatno opravili analize pogostnosti pojavljanj obravnavanih zemljepisnih imen ter njihovih različic v jezikovnem korpusu Gigafida, elektronski zbirki avtentičnih besedil, nastali po vnaprej določenih merilih in opremljeni z orodji, ki omogočajo večplastno iskanje jezikovnih podatkov. Korpus Gigafida, ki vsebuje skoraj 1,2 milijarde besed, je obsežna zbirka slovenskih besedil najrazličnejših zvrsti, od dnevnih časopisov in revij do knjižnih publikacij vseh vrst (leposlovje, učbeniki, stvarna literatura), spletnih besedil, prepisov parlamentarnih govorov in podobno (Gigafida 2017). Pregledali smo tudi zapise v Jezikovni svetovalnici Inštituta za slovenski jezik Frana Ramovša ZRC SAZU in tam našli primere iz obravnavane tematike $\mathrm{v}$ tematskih področjih besedotvorje (tematska sklopa besedotvorne dvojnice, svojilni pridevnik), etimologija (izvor zemljepisnega imena), oblikoslovje (mešanje sklanjatev, predlog, sklanjanje lastnih imen), pravopis (imena vinorodnih okolišev, ločila, mala ali velika začetnica, nadomestna imena, podomačevanje, posebna pisna znamenja, prečrkovanje, prevzete besede in besedne zveze, stvarna lastna imena, zemljepisna imena, znak za stopinje) in skladnja (besedna zveza, predložna zveza, večbesedne lastnoimenske zveze, zveze z desnim prilastkom) (Jezikovna svetovalnica 2017). Čeprav se z nekaterimi pogledi svetovalcev v podrobnostih ne strinjamo, so ti zapisi prvovrsten vir za poglobljeno spoznavanje zapletenosti rabe zemljepisnih imen. Kako so posamezni eksonimi zastopani in zapisani v slovenskih referenčnih atlasih sveta, si je mogoče ogledati v Preglednici eksonimov (2014).

\section{4 Še o imenih držav}

Kot že povedano, smo problematična imena držav že predstavili (Kladnik in Perko 2007; 2015a) ter pri tem še posebej podrobno predstavili poimenovanji Južne Afrike in Moldavije (Kladnik in Perko 2015b). Tudi za Vzhodni Timor in Slonokoščeno obalo si diplomati obeh krčevito prizadevajo, da bi se tudi na mednarodni ravni uveljavili izključno njihovi domači poimenovanji Timor-Leste oziroma Côte d'Ivoire. Si predstavljate, da bi ju tako imenovali v slovenščini, podobno, kot so ju na primer v angleščino že uvedli Britanci, ki so najprej po svetu spremenili na milijone izvornih imen, zdaj pa nekritično 
sprejemajo tovrstna vsiljevanja. Oba slovenska eksonima sta namreč zelo močno zakoreninjena in ju je zaradi možnosti pregibanja ter tvorjenja pridevnikov le kot takšna mogoče vključiti v slovenski jezik. Res pa je, da smo se sčasoma privadili tudi na soroden način vsiljenim imenom Bangladeš, Šrilanka in Mjanmar. In prav tako je res, da se vse, tudi jezik, nenehno spreminja.

Pregled nekaj preostalih nepoenotenih imen držav in najpomembnejših odvisnih ozemelj razkriva, da se nekatera imena, ki jih je leta 2007 standardiziral KSZI VRS, v širši javnosti (še) niso uveljavila. To razkriva analiza jezikovnega korpusa Gigafida (preglednica 1).

KSZI VRS je podomačil vsa imena s standardizacijskega seznama, razen imen odvisnih ozemelj Macau, Mayotte, Niue in Pitcairn ter neodvisne države Sierra Leone, za katera so njegovi člani menili, da je bolje, če jih pustijo v endonimski obliki ali obliki, transaliterirani skladno z mednarodno veljavnimi latinizacijskimi ključi. S poznejšo vključitvijo Kanalskih otokov na seznam ter razpustitvijo Nizozemskih Antilov so se na seznamu znašla tudi imena otoških odvisnih ozemelj Guernsey, Jersey in Curaçao, ki jih zaradi njihovega tradicionalno zakoreninjenega latiničnega zapisa prav tako niso domačili.

Glede na pogostnost rabe izstopa nepoenotenost imenske dvojnice Saudova Arabija/Saudska Arabija, ki pa je glede na število pojavljanj v Gigafidi vendarle krepko v prid sicer nestandardizirane, a v pravopisu (Slovenski pravopis 2001) navedene imenske različice Savdska Arabija. V Gigafidi kar 96 zapisov imena te države navaja vmesno različico s podomačeno svojilnopridevniško obliko Savdova Arabija, pojavljajo pa se še različice Saudijska Arabija (18-krat), Savdijska Arabija (16-krat) in celo Saudi Arabija (4-krat). O ustreznem imenu te države je bilo govora tudi v Jezikovni svetovalnici (Dobrovoljc in Weiss 2016), kjer je med drugim omenjeno, da je ime, ki je povsem enako zdajšnji standardizirani imenski obliki Saudova Arabija, predpisal že slovenski pravopis iz leta 1962, zapis pa se konča z mislijo: »... Sodeč po pogostnosti, bi tudi danes pravopisci dali prednost uveljavljeni obliki Savdska Arabija, ki je sicer - ne glede na izvor pridevnika - normirana tudi v drugih evropskih slovanskih jezikih (hr. Saudijska Arabija, češ. Saúdská Arábie, pol. Arabia Saudyjska, rus. Саудовская Аравия), izkazuje pa tudi živo pridevniško

Preglednica 1: Nekaj preostalih nepoenotenih imen držav in najpomembnejših odvisnih ozemelj ter pogostnost njihovega pojavljanja v jezikovnem korpusu Gigafida (2017).

\begin{tabular}{|c|c|c|c|c|c|}
\hline $\begin{array}{l}\text { leta } 2007 \\
\text { standardizirano } \\
\text { ime }\end{array}$ & $\begin{array}{l}\text { število navedb } \\
\text { (delež v \%) }\end{array}$ & $\begin{array}{l}\text { druga imenska } \\
\text { različica (endo- } \\
\text { nim ali drugačen } \\
\text { eksonim) }\end{array}$ & $\begin{array}{l}\text { število navedb } \\
\text { (delež v \%) }\end{array}$ & $\begin{array}{l}\text { morebitna } \\
\text { tretja imenska } \\
\text { različica }\end{array}$ & število navedb \\
\hline Gvadelup & $0(0,0)$ & Guadeloupe & $264(100,0)$ & Guadaloupe & 15 \\
\hline Kajmanji otoki & $0(0,0)$ & Kajmanski otoki & $547(100,0)$ & - & - \\
\hline Marijanski otoki & $7(21,2)$ & Marianski otoki & $26(78,8)$ & - & - \\
\hline Martinik & $118(33,6)$ & Martinique & $233(66,4)$ & - & - \\
\hline Mjanmar & $1754(53,4)$ & Burma & $1529(46,6)$ & Myanmar & 151 \\
\hline $\begin{array}{l}\text { Papuanska Nova } \\
\text { Gvineja }\end{array}$ & $0(0,0)$ & $\begin{array}{l}\text { Papua Nova } \\
\text { Gvineja }\end{array}$ & $648(100,0)$ & - & - \\
\hline Saudova Arabija & $265(4,3)$ & Savdska Arabija & $5874(95,7)$ & Savdova Arabija & 96 \\
\hline $\begin{array}{l}\text { Slonokoščena } \\
\text { obala }\end{array}$ & $3948(99,9)$ & Côte d'Ivoire & $5(0,1)$ & Ivory Coast & 9 \\
\hline Tokelav & $1(4,2)$ & Tokelau & $23(95,8)$ & - & - \\
\hline Vzhodni Kongo & $24(3,3)$ & $\begin{array}{l}\text { Demokratična } \\
\text { republika Kongo }\end{array}$ & $694(96,7)$ & - & - \\
\hline Vzhodni Timor & $1518(99,5)$ & Timor-Leste & $8(0,5)$ & - & - \\
\hline Zahodni Kongo & $0(0,0)$ & Republika Kongo & $766(100,0)$ & - & - \\
\hline
\end{tabular}


obliko (savdskoarabski). /... / O tem, katero obliko bo v nastajajočem novem pravopisu izbrala na osnovi vsega povedanega in tega, kar ste tudi sami navedli kot dejstvo, pa je pred obravnavo tega vprašanja $v$ komisiji preuranjeno trditi, zato je treba na odločitev komisije še počakati ...«. V odgovoru je govora tudi o Papuanski Novi Gvineji, ki ji je še podrobnejši zapis namenjen v nekaj mesecev mlajši Jezikovni svetovalnici (Dobrovoljc 2017a), v katerem je njegova avtorica zapisala: »... V odgovoru »Saudova « ali "Savdska" Arabija? je omenjena tudi neposrečena podomačitev imena Papua Nova Gvineja $v$ Papuanska Nova Gvineja. Neposrečena zato, ker imeni Papua in Nova Gvineja nista v podrednem razmerju, temveč $v$ prirednem, zato bi bilo bolj upravičeno nakazati slednje tudi z vezajem, kot ločilom, ki ponazarja zvezo dveh enakovrednih enot. Na povedano opozarja tudi raziskovalec antropolog dr. Borut Telban, ki že vrsto let opravlja terensko delo na Papui Novi Gvineji.«

Kljub podrobni obrazložitvi za uvedbo imen Vzhodni Kongo in Zahodni Kongo (Kladnik in Perko 2007; 2013b; 2015a), usmeritvi, naj kratka imena ne bi bila enaka uradnim polnim imenom ter zgledu v imenih Južna in Severna Koreja oziroma pred tem Južni in Severni Vietnam, se ti imeni ne v strokovni ne v laični javnosti še nista "prijeli«. Laična javnost ju niti ne more poznati, saj so bile razprave objavljene le v geografski periodiki in monografiji ter jezikoslovni monografiji. Kako se bosta uveljavili, je $\mathrm{v}$ precejšnji meri odvisno od njune morebitne vključitve v slovarski del nastajajočega novega pravopisa, o čemer se bo treba še dogovoriti.

Pričakovati je, da se bodo v novem pravopisu uveljavila vsa v sedanji rabi še nepoenotena imena držav, poimenovanih po svetnikih. Pravilo o njihovem obveznem domačenju vsebuje že aktualni pravopis (Slovenski pravopis 2001). Stanje njihove rabe, kot ga je registriral korpus Gigafida, je predstavljeno v preglednici 2.

Preglednica 2: Pogostnost pojavljanja nekaterih nepoenotenih imen držav in najpomembnejših odvisnih ozemelj, poimenovanih po svetnikih ("upoštevana so le imena, ki se nanašajo na poimenovanje države) v jezikovnem korpusu Gigafida (2017).

\begin{tabular}{|c|c|c|c|c|c|}
\hline $\begin{array}{l}\text { leta } 2007 \\
\text { standardizirano } \\
\text { ime }\end{array}$ & $\begin{array}{l}\text { število navedb } \\
\text { (delež v \%) }\end{array}$ & $\begin{array}{l}\text { druga imenska } \\
\text { različica (endo- } \\
\text { nim ali drugačen } \\
\text { eksonim) }\end{array}$ & $\begin{array}{l}\text { število navedb } \\
\text { (delež v \%) }\end{array}$ & $\begin{array}{l}\text { morebitna } \\
\text { tretja imenska } \\
\text { različica } \\
\text { (napačno ime } \\
\text { ali endonim) }\end{array}$ & število navedb \\
\hline $\begin{array}{l}\text { Mavricij } \\
\text { (slika 2) }\end{array}$ & $202(23,2)$ & Mauritius & $670(76,8)$ & $\begin{array}{l}\text { Mavricius/ } \\
\text { Mauricius/ } \\
\text { Mauritius }\end{array}$ & 359 \\
\hline Sveta Helena & $171^{*}(97,7)$ & Saint Helena & $4(2,3)$ & - & - \\
\hline Sveta Lucija & $53^{*}(77,9)$ & Saint Lucia & $15(22,1)$ & Saint Lucija & 1 \\
\hline $\begin{array}{l}\text { Sveti Krištof } \\
\text { in Nevis }\end{array}$ & $12(35,3)$ & $\begin{array}{l}\text { Saint Kitts } \\
\text { in Nevis }\end{array}$ & $22(64,7)$ & $\begin{array}{l}\text { Saint Kitts ter } \\
\text { Nevis/Saint Kitts } \\
\text { and Nevis/Saint } \\
\text { Kitts et Nevis }\end{array}$ & 7 \\
\hline $\begin{array}{l}\text { Sveti Tomaž in } \\
\text { Princ (slika 1) }\end{array}$ & $0(0,0)$ & $\begin{array}{l}\text { São Tomé in } \\
\text { Príncipe }\end{array}$ & $53(100,0)$ & - & - \\
\hline $\begin{array}{l}\text { Sveti Vincencij in } \\
\text { Grenadine/Sveti } \\
\text { Vincenc in } \\
\text { Grenadini }\end{array}$ & $3(11,5)$ & $\begin{array}{l}\text { Saint Vincent in } \\
\text { Grenadine/Saint } \\
\text { Vincent in } \\
\text { Grenadini }\end{array}$ & $23(88,5)$ & $\begin{array}{l}\text { Saint Vincent in } \\
\text { Grenada/Saint } \\
\text { Vincent in } \\
\text { Grenadin/Saint } \\
\text { Vincenc in } \\
\text { Grenadines }\end{array}$ & 3 \\
\hline
\end{tabular}




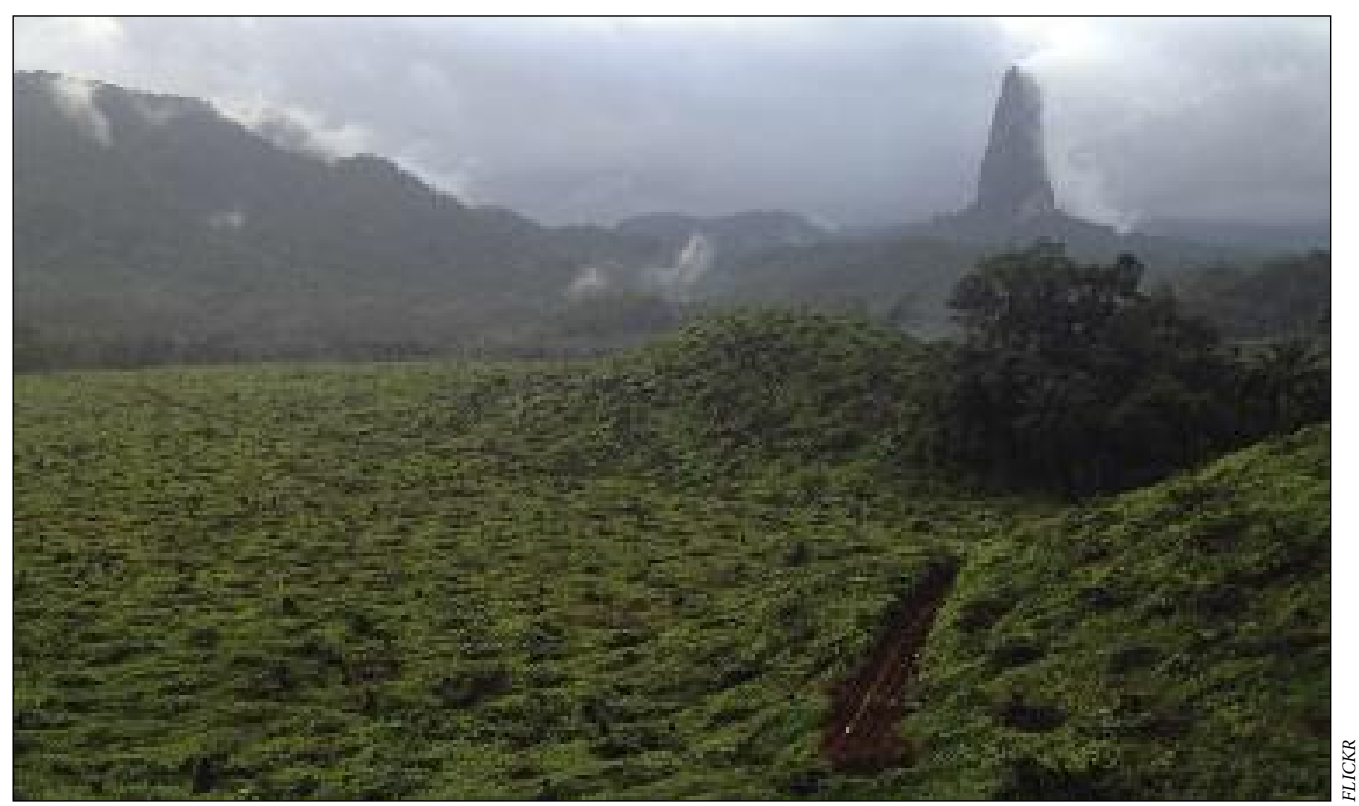

Slika 1: Med imeni držav je skoraj najtežje pravilno zapisati ime države São Tomé in Príncipe v Gvinejskem zalivu, ki bo postalo bolj poenoteno z uvedbo podomačene imenske različice Sveti Tomaž in Princ. Na fotografiji je 668 m visoka, drzno oblikovana vzpetina Cão Grande na otoku Sveti Tomaž.

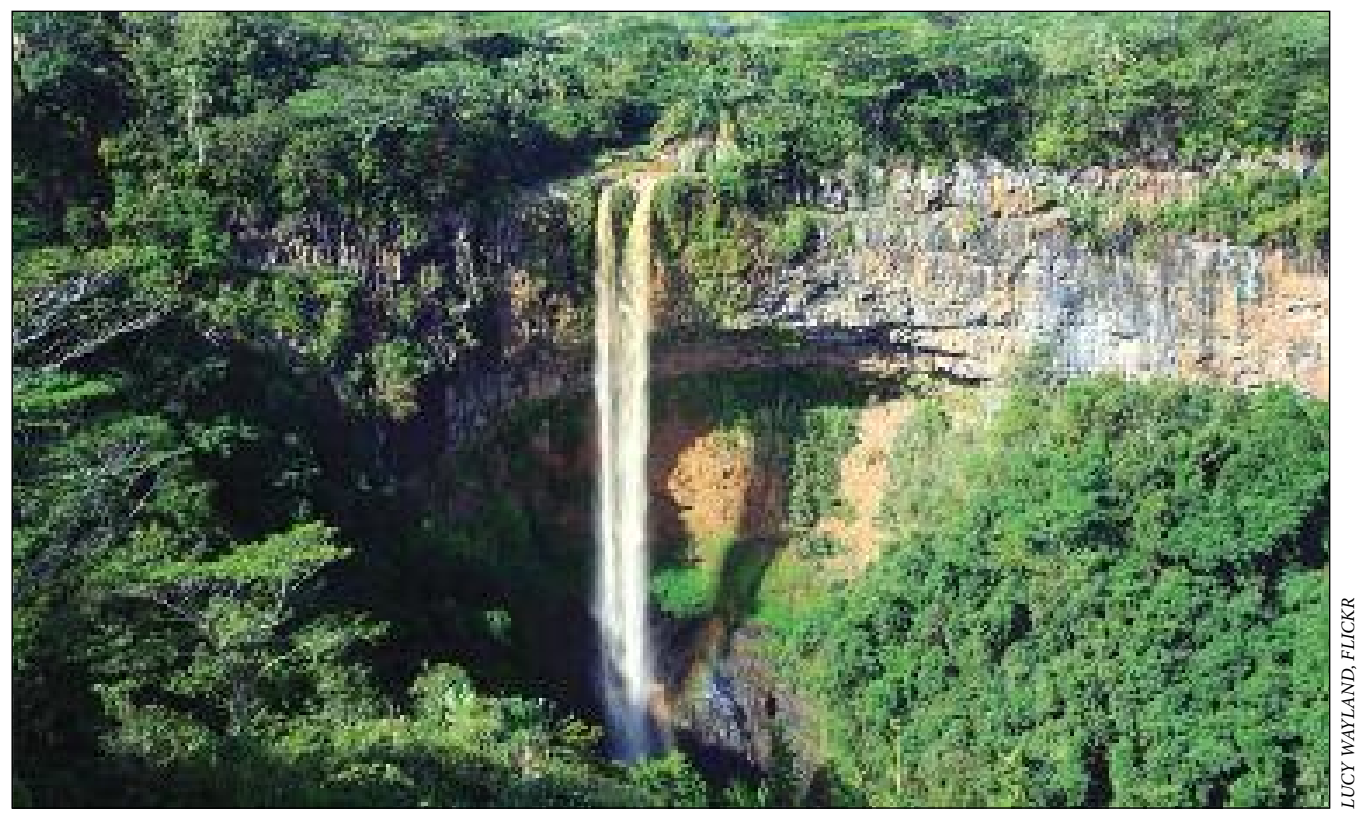

Slika 2: Tudi raba imena države Mavricij je za zdaj še trd oreh, kar je še posebej razvidno pri oglaševanju turističnih agencij, ki bolj slabo skrbijo za jezikovno neoporečnost svojih besedil. Otoška državica slovi tudi po slikovitem slapu Chamarel. 
Čeprav je zapisovanje imen teh držav težavno in zato neenotno, se $\mathrm{z}$ uvedbo podomačenih imenskih različic deleži takšne rabe povečujejo, v primerih Svete Lucije in Svete Helene pa je podomačena oblika že skoraj povsem prevladala. Izjema pri domačenju po svetnikih poimenovanih držav je San Marino. Zaradi njene bližine in s tem boljše poznanosti so se člani Podkomisije za imena držav pri KSZI VRS odločili, da bi bilo slovenjenje preveč radikalen poseg in zato ohranili njeno izvirno ime. Takšnega uporabljajo tudi v večini drugih pomembnejših jezikov, razen v francoščini, v kateri državici na Apeninskem polotoku pravijo Saint-Marin (Preglednica eksonimov 2014). O poimenovanju te skupine držav se lahko seznanimo tudi v Jezikovni svetovalnici (Dobrovoljc 2015c; Dobrovoljc in Weiss 2016; Dobrovoljc 2017a).

Med državami z za zdaj še neenotno imensko rabo velja izpostaviti tudi skupino prevladujočih muslimanskih držav v osrednji Aziji, ki so nastale z osamosvojitvijo nekdanjih sovjetskih republik. Podobno kot za sosednji državi Pakistan in Afganistan so jim poenoteno določili končnico -stan, kar v turškourdujsko-iranskem jezikovnem okolju pomeni »država" (Kladnik 2005a, 17). Aktualni pravopis podpira nesistemsko rabo, saj se nekatera imena končajo s končnico -ija (Kirgizija, Turkmenija), ki izhaja iz nekoč kolonialnega ruskega jezika, druga pa s končnico -stan (Kazahstan, Tadžikistan, Uzbekistan). To močno vpliva na dejansko rabo, ki jo beleži jezikovni korpus Gigafida (preglednica 3).

Opazno je, da je končnica -ija še vedno prevladujoča pri poimenovanju Kirgizistana oziroma Kirgizije (slika 3). Dokaj pogosta je tudi pri Turkmenistanu oziroma Turkmeniji, kjer pa se raba postopoma preusmerja k standardizirani imenski obliki. S predvideno vključitvijo standardizirane imenske različice v novi slovenski pravopis se bo stanje na področju ustrezne rabe zagotovo izboljšalo. Pri preostalih treh državah se končnica -ija le redko pojavlja in v primeru Kazahija zveni naravnost anahronistično. V primerih Kazahstana in Kirgizistana velja opozoriti še na dokaj številčno napačno rabo teh imen (na primer Kazakstan in Kirgistan), ki jo gre pripisati neznanju.

Neenotnost se kaže tudi v pridevniških izpeljankah iz imen nekaterih držav, kar je v geografiji pomembno z vidika ustreznih poimenovanj po njih poimenovanih pojavov oziroma topografskih objektov, denimo Etiopsko višavje/Etiopijsko višavje, Kongovska kotlina/Kongoška kotlina, Sirska puščava/Sirijska puščava in podobno. Nekaj najbolj opaznih razhajanj tovrstnih pridevniških oblik je prikazanih v preglednici 4.

Iz nje je razvidno, da se krajše oblike uporabljajo praviloma pogosteje od daljših; izjema je pridevnik somalijski, ki je povsem enakovreden krajši različici somalski. Te besedotvorne dvojnice so lahko posledica različnih izhodišč. Tako je na primer pridevnik egiptovski tvorjen iz imena države Egipt, pridevnik egipčanski pa iz imena njenega prebivalca Egipčan (Dobrovoljc in Weiss 2016). Podobno je pri neenotni pridevniški izpeljanki gruzijski oziroma guzinski, o čemer je pripravljena podrobna razlaga v Jezikovni svetovalnici (Snoj 2013), kjer je zapletenost rabe zaobjeta že v vprašanju samem. Ime

Preglednica 3: Pogostnost pojavljanja nepoenotenih imen srednjeazijskih držav, nastalih po razpadu Sovjetske zveze, v jezikovnem korpusu Gigafida (2017).

\begin{tabular}{lclclc}
\hline $\begin{array}{l}\text { standardizirano } \\
\text { ime }\end{array}$ & $\begin{array}{c}\text { število navedb } \\
(\text { delež v \%) }\end{array}$ & $\begin{array}{l}\text { druga } \\
\text { poslovenjena } \\
\text { imenska različica }\end{array}$ & $\begin{array}{c}\text { število navedb } \\
\text { (delež v \%) }\end{array}$ & $\begin{array}{l}\text { morebitna } \\
\text { tretja imenska } \\
\text { različica }\end{array}$ & število navedb \\
\hline Kazahstan & $6109(100,0)$ & Kazahija & $2(0,0)$ & $\begin{array}{l}\text { Kazakstan/ } \\
\text { Kazakhstan }\end{array}$ & 61 \\
Kirgizistan & $651(29,2)$ & Kirgizija & $1581(70,8)$ & Kirgistan & 98 \\
Tadžikistan & $1281(96,5)$ & Tadžikija & $47(3,5)$ & - & - \\
Turkmenistan & $763(67,9)$ & Turkmenija & $361(32,1)$ & - & - \\
Uzbekistan & $2632(98,8)$ & Uzbekija & $33(1,2)$ & - & - \\
\hline
\end{tabular}


Gruzija smo Slovenci prevzeli prek ruščine (s prevodi klasikov ruske literature) že v 19. stoletju, enako tudi pridevniško izpeljanko gruzínski in etnonim Gruzínec (rusko sicer Gruzin). Standardizirala sta jih tudi Slovenski pravopis iz leta 1962 in Slovar slovenskega knjižnega jezika iz leta 1991. Zaradi nizke pismenosti nekaterih novinarjev sta se v slovenskih medijih že pred časom začeli pojavljati nestandardizirani obliki grúzijski oziroma Grúzijec, kakršna je znana v hrvaščini in srbščini (tam seveda Gruzijac).

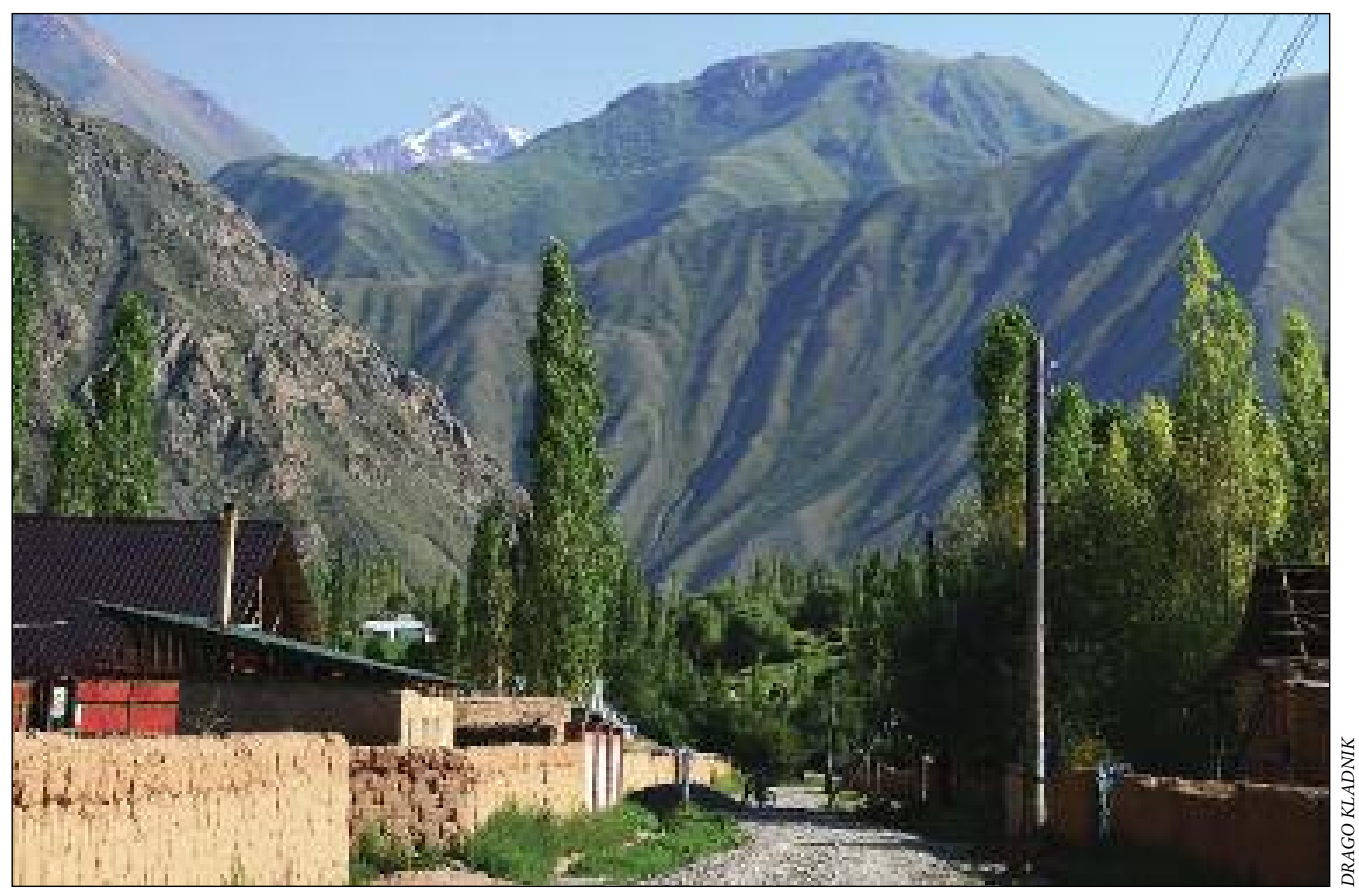

Slika 3: Zaradi priporočene rabe imenske oblike Kirgizija v aktualnem pravopisu je za zdaj poimenovanje te gorate srednjeazijske države neusklajeno. Na fotografiji je vas Kyzyl-Oi v njenem osrednjem delu.

Preglednica 4: Pogostnost rabe nekaterih nepoenotenih pridevniških izpeljank iz imen držav v jezikovnem korpusu Gigafida (2017).

\begin{tabular}{lclclc}
\hline $\begin{array}{l}\text { prva različica } \\
\text { pridevniške } \\
\text { izpeljanke }\end{array}$ & $\begin{array}{c}\text { število navedb } \\
(\text { delež v \%) }\end{array}$ & $\begin{array}{l}\text { druga različica } \\
\text { pridevniške } \\
\text { izpeljanke }\end{array}$ & $\begin{array}{c}\text { število navedb } \\
\text { (delež v \%) }\end{array}$ & $\begin{array}{l}\text { morebitna tretja } \\
\text { različica } \\
\text { pridevniške } \\
\text { izpeljanke }\end{array}$ & število navedb \\
\hline egiptovski & $9362(63,1)$ & egipčanski & $5475(36,9)$ & - & - \\
etiopski & $2207(95,7)$ & etiopijski & $100(4,3)$ & - & - \\
gruzijski & $2942(56,9)$ & gruzinski & $2233(43,1)$ & - & - \\
jordanski & $2685(99,8)$ & jordanijski & $5(0,2)$ & - & - \\
kongovski & $531(72,2)$ & kongoški & $215(27,8)$ & - & - \\
litvanski & $749(19,8)$ & litovski & $3026(80,2)$ & litavski & 15 \\
moldavski & $1154(93,1)$ & moldavijski & $85(6,9)$ & moldovski & 88 \\
sirski & $2986(90,2)$ & sirijski & $323(9,8)$ & - & - \\
somalski & $728(50,6)$ & somalijski & $711(49,4)$ & - & - \\
\hline
\end{tabular}


Izvirne gruzinske imenske oblike so povsem drugačne: Sakartvelo za ime države (Gruzija), Kartveli za ime prebivalca (Gruzinec) in Kartuli za pridevniško izpeljanko (gruzinski). Pripravljavec odgovora se glede ustreznejših oblik ni želel opredeliti in jim pripisuje enakovreden značaj, glede na izkušnje pa za prihodnost napoveduje, da bosta prevladali različici Gruzijec in gruzijski (Snoj 2013).

Nepoenotena je tudi raba imena države Združeno kraljestvo, kar je njeno uradno kratko ime, oziroma Velika Britanija. Za zdaj je ime Velika Britanija močno prevladujoče (v Gigafidi ima kar 55.666 zadetkov, Združeno kraljestvo pa le 2530), kar pa ni ustrezno, saj gre pravzaprav za ime največjega otoka v Britanskem otočju (poleg Velike Britanije to otoško skupino sestavljajo otok Irska, manjši okoliški otoki ter bližnje otoške skupine Shetlandski otoki, Orkneyjski otoki, Hebridi in druge). Pričakovati je, da se bo sčasoma uveljavila primernejša imenska različica Združeno kraljestvo, še posebej, ko bo ta predvidoma vključena v novi slovenski pravopis. Omeniti velja še, da sta za to državo neformalno v rabi tudi nadomestni imeni Anglija, ki je kot dežela seveda le poglavitni sestavni del Združenega kraljestva, in Otok, ki je pravzaprav vzdevek otoka Velika Britanija (Dobrovoljc 2013c).

V zvezi z rabo občnoimenskih izrazov otočje/otoki naj povemo, da se je Podkomisija za imena držav pri KSZI VRS odločila, naj se za vsa imena otoških administrativnih enot uporablja občnoimenska množinska oblika otoki, kar je posebej pomembno za ustrezno rabo imen neodvisnih držav Marshallovi otoki, Salomonovi otoki in Zelenortski otoki ter imen mnogih odvisnih ozemelj (na primer Alandski otoki, Cookovi otoki, Ferski otoki, Kokosovi otoki, Severni Marijanski otoki), medtem ko naj bi bila oblika otočje rezervirana za morfološko otoško obliko z mnogimi otoki, naj bo to otoška skupina, sestavljena iz nekaj večjih otokov in številnih manjših (na primer Britansko otočje, Japonsko otočje) ali skupina, ki jo sestavljajo številni majhni otoki, pogosto koralnega nastanka (na primer Cookovo otočje - ne v pomenu deloma neodvisne državne tvorbe, Ekvatorsko otočje, Deviško otočje). Z občnoimensko obliko otoki pa označujemo tudi morfološko otoško obliko z nekaj dokaj enakovredno velikimi otoki (na primer Azorski otoki, Havajski otoki, Kurilski otoki, Zelenortski otoki - ne v pomenu države), ki jih pogosto navajamo tudi v skrajšani, zgolj enobesedni lastnoimenski različici (na primer Azori, Havaji, Kurili) (Kladnik in Perko 2015a, 239).

Zaradi neustreznega priporočila za rabo imena države Lihtenštajn v aktualnem pravopisu, kjer je navedeno le njeno izvirno ime Liechtenstein, ki je tako v nasprotju s standardizirano podomačeno obliko kot členom $185 \mathrm{v}$ aktualnem pravopisu - ta pravi, da imena držav podomačujemo, še posebej, če so izpeljana iz družinskih imen oziroma imen rodbin - je nepoenotena tudi raba imena te žepne alpske državice med Avstrijo in Švico. To obravnava tudi zapis v Jezikovni svetovalnici (Dobrovoljc 2015a). Korpus Gigafida (2017) razkriva močno prevlado izvirnega imena (3101 zadetek), saj ima podomačena oblika imena vsega 107 zadetkov. Na drugi strani je opazna močna prevlada Lihtenštajnu sorodne podomačene imenske oblike Luksemburg (13.716 zadetkov) nad rabo njene izvirne imenske različice Luxembourg (1566 zadetkov). Pri imenu te države je treba omeniti še precejšnjo pogostnost pojavljanja nesistemske imenske različice Luxemburg (893 zadetkov).

Omenimo še, da se je češko politično vodstvo aprila 2016 odločilo spremeniti kratko uradno ime Češka republika v Češka. Ime Češka je bilo vključeno v seznam držav standarda ISO 316626 . septembra istega leta, zatem je raba spremenjenega kratkega imena začela strmo naraščati tako v domači češki kot mednarodni javnosti (medmrežje 1). Ime Češka smo Slovenci kot standardizirano kratko ime prevladujoče uporabljali že prej. To potrjuje korpus Gigafida, kjer ima imenska različica Češka 35.935 zadetkov (96,6\%), različica Češka republika pa le 1251.

Težave ustrezne rabe pa se ne pojavljajo le pri imenih držav in odvisnih ozemelj v prvem sklonu oziroma imenovalniku in njihovih pridevniških izpeljankah, ampak tudi pri rabi ustreznega predloga v mestniku. O splošnih pravilih ustrezne rabe predlogov je v Jezikovni svetovalnici pripravil zapis Marko Snoj (2016). V njem je med drugim zapisano, da se pred imeni držav, dežel, pokrajin in tem podobnih zemljepisnih enot glede na vprašanji kje? in kam? praviloma uporablja predlog $v$ : $v$ Italiji, $v$ Italijo, $v$ Nemčiji, v Nemčijo, $v$ Rusiji, $v$ Rusijo, na vprašanje od kod? pa predlog iz: iz Italije, iz Nemčije, iz Rusije. Izjeme so imena, tvorjena s pripono -sko oziroma -ško: na Češkem, na Češko, na Danskem, na Dansko, 
na Norveškem, na Norveško. Imena srednjega slovničnega spola na -sko, -ško se dandanes uporabljajo le še v mestniku, na primer na Madžarskem, in tožilniku, če pred imenom ni nobenega prilastka, na primer »Šla je na Madžarsko«, v starejšem jeziku pa so se tudi v drugih sklonih, na primer »Prihaja $z$ Madžarskega«. Namesto imen na -sko, -ško se v drugih sklonih (in tožilniku, pred katerim stoji prilastek), zdaj uporabljajo imena na -ska, -ška, torej Češka, Danska, Norveška, ki imajo pred sabo predloga $v$ oziroma $i z$, na primer »Prejmite pozdrave iz Danske«, „Šla je v svojo rodno Norveško" (zaimenska oblika svojo dokazuje, da je uporabljeno ime ženskega spola Norveška, ne pa ime srednjega spola Norveško).

Še največ težav je povezanih $\mathrm{z}$ rabo ustreznega predloga pri sklanjanju imen otoških držav in odvisnih ozemelj (preglednica 5). Čeprav je o tem Snoj (2016) zapisal: »Predloga na in z se uporabljata tudi pred večino imen otoških držav (in podobnih zemljepisnih enot): na Malti, na Islandiji, na Novi Zelandiji, na Madagaskarju, na Fidžiju, na Tenerifu, tudi polotoških [zemljepisnih pojmov, opomba avtorjev]:

Preglednica 5: Pogostnost rabe neenotnih predlogov v petem sklonu pri nekaterih otoških državah in odvisnih ozemljih ("upoštevani so le zadetki, ki se neposredno nanašajo na obravnavano zemljepisno ime) v jezikovnem korpusu Gigafida (2017).

$\begin{array}{lclcll}\begin{array}{l}\text { raba } \\ \text { predloga } n a\end{array} & \text { število navedb } & \text { raba } & \text { število navedb } & \text { raba predloga } \\ & (\text { delež v \%) } & \text { predloga } v & \text { pri morebitni } & \text { število navedb } \\ & & & \begin{array}{l}\text { drugačni imenski } \\ \text { različici }\end{array} & \\ & & & \end{array}$

\begin{tabular}{|c|c|c|c|c|c|}
\hline na Azorih & $138(99,3)$ & v Azorih & $1(0,7)$ & - & - \\
\hline na Bahrajnu & $8(0,7)$ & v Bahrajnu & $1135(99,3)$ & v Bahreinu & 83 \\
\hline na Barbadosu & $331(98,2)$ & v Barbadosu & $6(1,8)$ & - & - \\
\hline $\begin{array}{l}\text { na Dominikanski } \\
\text { republiki }\end{array}$ & $654(99,5)$ & $\begin{array}{l}\text { v Dominikanski } \\
\text { republiki }\end{array}$ & $13(0,5)$ & - & - \\
\hline na Grenadi & $54(54,0)$ & v Grenadi & $46(46,0)$ & - & - \\
\hline na Haitiju & $1617(98,4)$ & v Haitiju & $27(1,6)$ & - & - \\
\hline na Hongkongu & $4^{*}(0,1)$ & v Hongkongu & $3148(99,9)$ & v Hong Kongu & 641 \\
\hline na Komorih & $18(72,0)$ & v Komorih & $7(28,0)$ & - & - \\
\hline na Kubi & $5994(99,5)$ & v Kubi & $28^{*}(0,5)$ & - & - \\
\hline na Madagaskarju & $1195(97,9)$ & v Madagaskarju & $26(2,1)$ & - & - \\
\hline na Malti & $2349(99,9)$ & v Malti & $2^{*}(0,1)$ & - & - \\
\hline na Novi Kaledoniji & $18(34,6)$ & v Novi Kaledoniji & $34(65,4)$ & - & - \\
\hline na Novi Zelandiji & $3164(82,3)$ & v Novi Zelandiji & $679(17,7)$ & - & - \\
\hline $\begin{array}{l}\text { na Papui Novi } \\
\text { Gvineji }\end{array}$ & $210(70,0)$ & $\begin{array}{l}\text { v Papui Novi } \\
\text { Gvineji }\end{array}$ & $90(30,0)$ & - & - \\
\hline na Portoriku & $16(3,8)$ & v Portoriku & $410(96,2)$ & - & - \\
\hline na Sejšelih (slika 4) & $297(100,0)$ & v Sejšelih & $0(0,0)$ & - & - \\
\hline na Šrilanki & $837(81,1)$ & v Šrilanki & $195(18,9)$ & na Šri Lanki & 216 \\
\hline na Tajvanu & $1610(87,3)$ & v Tajvanu & $234(12,7)$ & na Taivanu & 5 \\
\hline na Tongi & $56(88,9)$ & v Tongi & $7(11,1)$ & - & - \\
\hline $\begin{array}{l}\text { na Trinidadu } \\
\text { in Tobagu }\end{array}$ & $18(39,1)$ & $\begin{array}{l}\text { v Trinidadu } \\
\text { in Tobagu }\end{array}$ & $28(60,9)$ & - & - \\
\hline $\begin{array}{l}\text { na Vzhodnem } \\
\text { Timorju }\end{array}$ & $463(81,4)$ & $\begin{array}{l}\text { v Vzhodnem } \\
\text { Timorju }\end{array}$ & $106(18,6)$ & - & - \\
\hline $\begin{array}{l}\text { na Zelenortskih } \\
\text { otokih }\end{array}$ & $90(99,0)$ & $\begin{array}{l}\text { v Zelenortskih } \\
\text { otokih }\end{array}$ & $1(1,0)$ & $\begin{array}{l}\text { na Kapverdskih } \\
\text { otokih }\end{array}$ & 9 \\
\hline
\end{tabular}


na Floridi, na Kamčatki, na Jukatanu, vendar je to le tendenca, ne pa pravilo, saj npr. rečemo v Singapurju, v Veliki Britaniji, v Trinidadu in Tobagu [temu primeru bi se dalo oporekati, opomba avtorjev], v Istri ... «, na nepoenoteno rabo v veliki meri vplivajo prav neustrezne navedbe v slovarskem delu aktualnega pravopisa (Slovenski pravopis 2001).

Pri otoških državah, pri katerih se na videz preprosto vprašanje izbire predloga $v$ ali na zaplete, če določeno ozemlje pojmujemo večdenotativno, torej tako kot politično skupnost (država Ciper, država $K u b a$ ), pri kateri se navadno odločamo za rabo predloga $v$ ( $v$ državi Ciper, $v$ državi Kuba), kot prvenstveno glede na njegovo otoško lego, pri kateri je v rabi predlog na (na Cipru, na Kubi).

Ob tem je treba razlikovati med (Kladnik in Perko 2015a):

- otoškimi državami, ki jih sestavlja večje število otokov in otoških skupin (na primer Fidži, Filipini, Indonezija, Japonska, Sejšeli),

- državami, ko sta na določenem otoku običajno dve državi (na primer Haiti in Dominikanska republika na otoku Hispaniola),

- državami, ki jih sestavljata dva glavna otoka (na primer Antigva in Barbuda, Sveti Krištof in Nevis, Trinidad in Tobago), ter

- državami, ki jih (poleg manjših okoliških otokov) sestavlja en sam glavni otok (na primer Bahrajn, Kuba, Madagaskar, Nauru, Šrilanka).

Medtem ko bi lahko pri predlogu $v$ poleg otoškega kopna upoštevali tudi pripadajoče morsko ozemlje, sta pri sicer prevladujočem predlogu na poudarjena otoška lega države oziroma njen kopenski del. Predlog $v$ se zdi smiseln tudi v primeru držav, ki jih sestavlja več otokov in otočij, na primer $v$ Indone$z i j i, v$ Japonski, vendar je v praksi tudi v teh primerih pogostejši predlog na, denimo na Filipinih, na Novi Zelandiji, na Sejšelih.

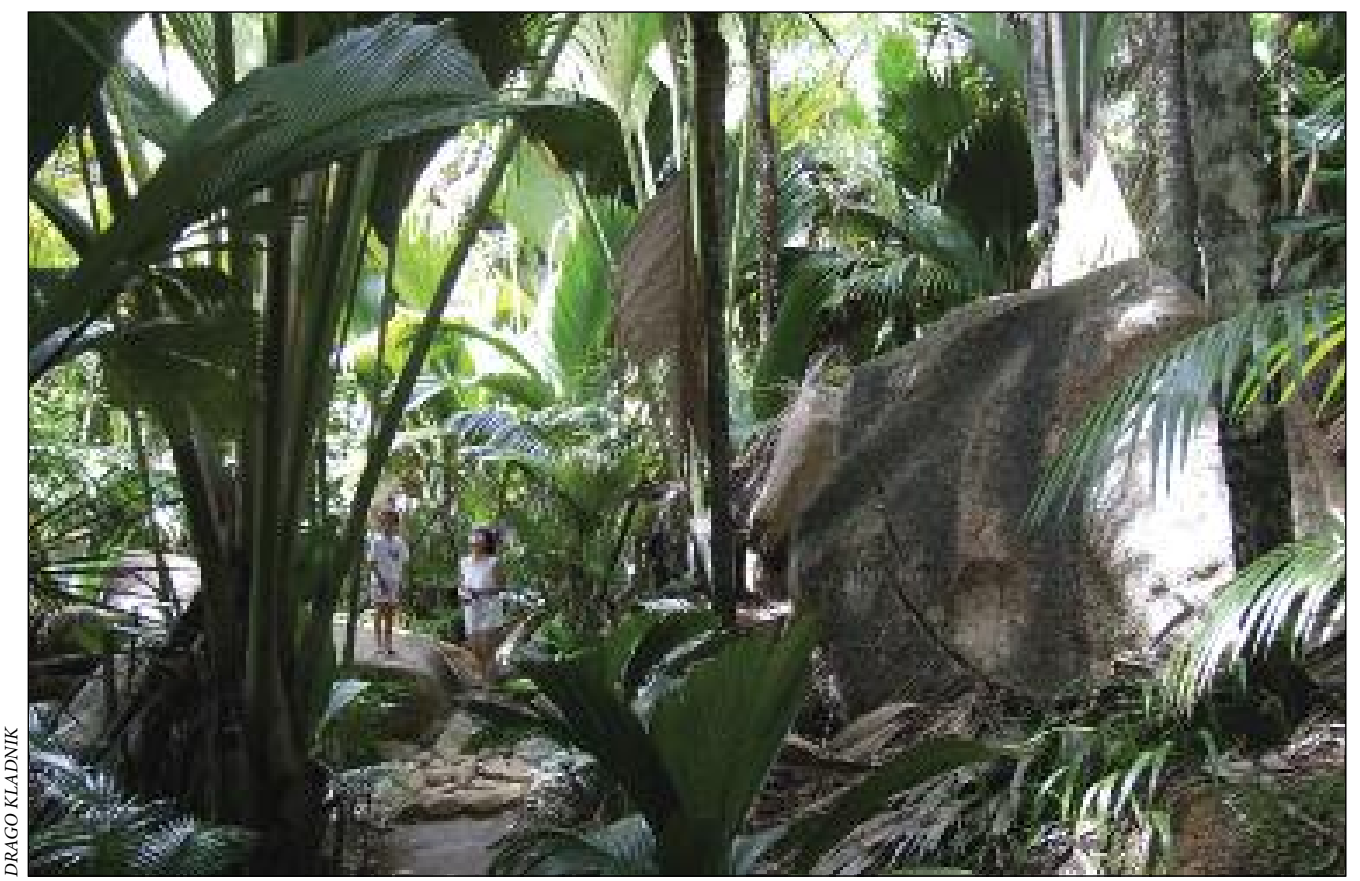

Slika 4: V naravnem rezervatu Vallée de Mai na Sejšelih oziroma na njihovem drugem največjem otoku Praslinu. Rezervat je kot endemično rastišče morskega kokosa (Lodoicea maldivica) od leta 1983 vpisan na UNESCO-v seznam svetovne naravne in kulturne dediščine. 
Predlagano pravilo je v veljavnem pravopisu izpeljano precej nesistematično. V njegovem slovarskem delu je med dobrimi šestdesetimi državami in najpomembnejšimi odvisnimi ozemlji, ki jih lahko opredelimo kot otoška, pri dveh tretjinah naveden predlog na, pri preostali tretjini pa je v večini primerov naveden predlog $v$. V večini primerov je eksplicitno navedeno, da gre za otoške države. Ker teh navedb pri nekaterih otoških državah ni, je ob njihovih imenih navedena zveza s predlogom $v$, lahko upravičeno sklepamo, da se pripravljavci iztočnic tega dejstva sploh niso zavedali. Ta misel se zazdi upravičena že pri pregledu imen nekaterih otokov, saj je na primer pri kanadskem otoku Nova Fundlandija kot mestnik navedena predložna zveza $v$ Novi Fundlandiji, predlog $v$ pa se za peti sklon pojavi tudi pri imenskih iztočnicah neodvisnih otoških držav Bahrajn, Dominika, Grenada, Nauru, Sveta Lucija, Sveti Krištof in Nevis, São Tomé in Principe (Sveti Tomaž in Princ), Sveti Vincenc in Grenadini (pravilno ime je Sveti Vincencij in Grenadine), Šrilanka, Tajvan, Tonga, Trinidad in Tobago ter Vanuatu in odvisnega otoškega ozemlja Portoriko. Tako je tudi v primerih otoške države Singapur in kitajskega odvisnega ozemlja Hongkong, ki sta prav tako otoški ozemeljski entiteti, vendar si zanju zaradi tradicionalne, že dokaj ustaljene rabe težko predstavljamo rabo predložne zveze na Singapurju oziroma na Hongkongu. Neenotnost je tudi pri navedbi predložnih zvez za imeni obeh neodvisnih držav na otoku Hispaniola v Karibih. Medtem ko je za vzhodno Dominikansko republiko uporabljena predložna zveza v Dominikanski republiki, je za zahodno Haiti uporabljena predložna zveza na Haitiju (Kladnik in Perko 2015a).

\section{Raba naselbinskih eksonimov}

Ker je problematika rabe eksonimov v vlogi naselbinskih imen zelo široka, se omejujemo le na prikaz nekaterih najbolj značilnih primerov. Precej jih je podrobneje obdelanih v Jezikovni svetovalnici, kar še posebej velja za razne vidike podomačevanja imen pomembnejših, od Slovenije bolj ali manj oddaljenih mest (Torkar 2012; Dobrovoljc 2013a; 2013b; 2013d; 2014a; 2014b; 2015b; Dobrovoljc s sodelavci 2016; Dobrovoljc 2017b; 2017c; Weiss 2017).

Naselbinskih zemljepisnih imen običajno ne domačimo in jih puščamo zapisana v izvirni obliki. To velja še zlasti za tista, ki so zapisana v eni od latiničnih pisav, izjema so nekatera imena pomembnejših mest (na primer Praga, Ženeva, Bruselj, Pariz), medtem ko naj bi skladno s trenutno veljavnimi predpisi aktualnega pravopisa (Slovenski pravopis 2001) zemljepisna imena, zapisana v nelatiničnih pisavah in ideogramih, podomačevali. O slovenjenju pa ne govorimo, če imamo za določeno naselje že uveljavljeno slovensko ime, navadno iz starejšega obdobja (na primer Dunaj, Carigrad, Benetke, Reka), ali če gre za naselje na dvojezičnem območju (Beljak, Celovec, Gorica, Trst). To so namreč izvorno slovenska in ne poslovenjena imena (Dobrovoljc 2014a; 2015b).

Opažamo, da se določena arhaična slovenska imena umikajo rabi imen v izvirniku (na primer Inomost, Monakovo, tudi Pulj in Sisek), z novimi družbenimi in političnimi okoliščinami pa se pojavljajo novi eksonimi. Tako na primer Slovencem zaradi nove evropske ureditve čedalje bližje mesto Luksemburg že slovenimo, čeprav je njegovo izvirno ime Lëtzebuerg v luksemburščini, Luxembourg v francoščini oziroma Luxemburg v nemščini. Težnje po podomačevanju lahko opazujemo tudi pri nekaterih drugih, družbeno bolj izpostavljenih mestih, še največkrat zaradi pridevnikov, izpeljanih iz njihovih imen, ko ti pridevniki označujejo katerega od aktualnih sprejetih sporazumov, deklaracij, reform ali česa podobnega. Med najbolj znane spadata primera države šengenskega območja in bolonjska reforma, pri čemer opažamo, da se ob pogosti uporabi lastno ime podomači ali da pride do pomenskega prenosa, na primer (Dobrovoljc 2014b):

- Schengen ali Šengen »kraj« proti šengen »območje s prostim prehajanjem meje« in

- Bologna (ta izvirna oblika imena ima v Gigafidi 11.438 zadetkov) ali Bolonja (podomačeno ime mesta ima le 33 zadetkov) »kraj« proti bolonja v navezavi na »šolsko reformo«.

Podomačevanje zemljepisnih in drugih lastnih imen temelji na slovenskem izgovoru izvirnih imen. Že pravopis iz leta 1962 določa, da v slovenščini besede, prevzete iz tujega jezika, pišemo »...na dva 
načina, $v$ tuji obliki ali po domači izgovarjavi ..... Merilo za ločevanje med podomačenim in nepodomačenim zapisom je področje rabe besede: prevzete besede, ki so »... omejene le na ozek krog strokovnjakov ali družbe ...«, ohranijo tujo obliko zapisa, prevzete besede, ki pa so »... v splošni rabi ...«, pišemo po domači izgovarjavi. Sodobno pravopisno načelo, da se obče prevzete besede v rabi sčasoma podomačijo, pri pisanju povzroča težave, saj temelji na idealiziranem uporabniku, ki dobro pozna zakonitosti jezi$\mathrm{ka}$ in ima tudi širši pogled na vlogo jezika v družbi. Prilagajanje tujega besedja zakonitostim slovenščine namreč ni povsem predvidljiv proces (Bizjak 2012, 64-65). Ob tem se lahko vprašamo, kakšni bi bili (sodobni) atlasi sveta, če bi v njih, skladno s pravopisnimi navodili, izgovorno podomačevali vsa imena iz nelatiničnih pisav. Dejansko bi bilo to zaradi praktičnih (nepoznavanje izvirne izgovarjave), tehničnih (na novo bi bilo treba zapisati na tisoče imen) in finančnih (zaradi skromnih možnosti prodaje na že zasičenem trgu nobena založba ne bi bila sposobna izvesti takšnega projekta) razlogov povsem neizvedljivo. K sreči se splošno domačenje zemljepisnih imen v pisni slovenščini ni nikdar in nikjer širše uveljavilo.

Pogačnik $(2012,82)$ meni, da bi pravopisna pravila morala odpraviti nepotrebno razliko med latiničnimi in nelatiničnimi pisavami, glasovno domačenje pa opredeliti kot (zasilno) možnost in ne pravilo. Vzpostavljeno bi moralo biti jasno razločevanje med izgovarjavo in pisavo, pripravljena pa bi morala biti tudi seznam izglasij iz čim več svetovnih jezikov (ne glede na pisavo), ki vplivajo na pregibanje, in konkreten seznam tistih imen, ki jih v slovenščini dejansko pišemo drugače, ne nujno le v glasovno podomačeni obliki.

Pri upoštevanju aktualnih pravopisnih navodil se v praksi pojavljajo pomembne nedoslednosti. To trditev lahko ponazorimo na primeru podomačevanja treh pomembnih mest iz jugovzhodne Azije, izvirno zapisanih $\mathrm{v}$ nelatiničnih pisavah oziroma ideogramih (preglednica 6).

Opazno je, da je raba teh imen izrazito neenotna. Še najbolj poenotena in skladna s pravopisnimi pravili je v primeru Hongkonga, medtem ko je pri Hošiminhu pogosta tudi raba imenske različice, zapisane narazen (ob njiju in le delno podomačeni različici Ho Chi Minh se pogosto uporablja tudi nekdanje ime v oblikah Saigon (395 zadetkov) in Sajgon (214 zadetkov)). Kamboško glavno mesto bi moralo biti skladno s pravopisnimi pravili ustrezno zapisano kot Pnompen, a takšnega zapisa v Gigafidi sploh ni. Krajši zapis o imenih Hošiminh in Pnompen (slika 5) je objavljen tudi v Jezikovni svetovalnici (Dobrovoljc 2013b).

Drug sklop težavne rabe eksonimov naselbinskih imen se nanaša na azijska mesta, ki so jim v zadnjem času spremenili ime, njihova nekdanja imena pa so bila že pred tem trdno uveljavljeni slovenski eksonimi (preglednica 7).

Indijskim mestom so ime spremenili v zadnjem desetletju 20. stoletja. Temu smo se v slovenščini prilagodili na različne načine. Medtem ko je za Mumbaj (slika 6) kljub zelo burni polpretekli zgodovini, prežeti $\mathrm{z}$ odmevnimi terorističnimi dejanji, še vedno v rahli prevladi raba starejšega eksonima Bom$b a j$, se v primeru Benaresa oziroma Čenaja pogosteje uporablja njun izvirni, prečrkovani endonimski

Preglednica 6: Pogostnost zapisov različic podomačenih imen nekaterih mest v jugovzhodni Aziji, izvirno zapisanih v nelatiničnih pisavah oziroma ideogramih, v jezikovnem korpusu Gigafida (2017).

\begin{tabular}{lclclc}
\hline $\begin{array}{l}\text { podomačeno } \\
\text { ime }\end{array}$ & $\begin{array}{c}\text { število navedb } \\
(\text { delež v \%) }\end{array}$ & $\begin{array}{l}\text { druga imenska } \\
\text { različica } \\
\text { podomačenega } \\
\text { imena }\end{array}$ & $\begin{array}{c}\text { število navedb } \\
(\text { delež v \%) }\end{array}$ & $\begin{array}{l}\text { morebitna tretja } \\
\text { imenska različica } \\
\text { podomačenega } \\
\text { imena }\end{array}$ & število navedb \\
\hline Hongkong & $6075(81,0)$ & Hong Kong & $1425(19,0)$ & - & - \\
Hošiminh & $152(60,1)$ & Ho Ši Minh & $101(39,9)$ & Ho Chi Minh & 37 \\
Phnom Penh & $411(93,8)$ & Pnom Penh & $27(7,2)$ & Pnom Pen & 15 \\
\hline
\end{tabular}


zapis. Povsem drugače je pri v slovenščini zelo trdno uveljavljenem eksonimu Kalkuta, ki je tako močno zasidran v javni rabi, da sprememba imena na pogostnost rabe sploh ni opazneje vplivala. V bistvu si je težko predstavljati, da bi namesto njega začeli uporabljati dokaj podobno bengalsko izvirno obliko Kolkata, čeprav se je na primer sčasoma to že zgodilo pri novih imenih držav Šrilanka (v Gigafidi ima 2466 zadetkov, oblika Šri Lanka 763 in Sri Lanka 196), Tajska (13.047 zadetkov) in Tajvan (7965 zadetkov). Te imenske oblike so v Gigafidi v veliki prevladi pred njihovimi nekdanjimi, starejšimi imeni Cejlon (293 zadetkov), Siam (287 zadetkov) in Formoza (91 zadetkov), ki se očitno uporabljajo le še v zgodovinskem kontekstu. Podobno se namesto nekdanjega poimenovanja indonezijskega otoka Celebes

Preglednica 7: Pogostnost zapisov različic podomačenih imen nekaterih mest $v$ Aziji, katerih ime se je pred časom spremenilo in imajo uveljavljen slovenski eksonim, v jezikovnem korpusu Gigafida (2017).

\begin{tabular}{lrlrlc}
$\begin{array}{l}\text { spremenjen } \\
\text { ali uveljavljen } \\
\text { slovenski } \\
\text { eksonim }\end{array}$ & $\begin{array}{c}\text { število navedb } \\
\text { (delež v \%) }\end{array}$ & $\begin{array}{l}\text { aktualen } \\
\text { endonim }\end{array}$ & $\begin{array}{c}\text { število navedb } \\
\text { (delež v \%) }\end{array}$ & $\begin{array}{l}\text { morebitna tretja } \\
\text { imenska različica } \\
\text { (star eksonim ali } \\
\text { nekdanji endonim) }\end{array}$ & število navedb \\
\hline Peking & $34.358(99,2)$ & Beijing & $275(0,8)$ & - & - \\
Čenaj & $72(36,7)$ & Chennai & $124(63,3)$ & Madras & 366 \\
Kalkuta & $1040(95,6)$ & Kolkata & $48(4,4)$ & Calcutta & 36 \\
Mumbaj & $795(81,1)$ & Mumbai & $185(18,9)$ & Bombaj & 837 \\
Nanking & $141(39,1)$ & Nanjing & $220(60,9)$ & - & - \\
Benares & $111(35,6)$ & Varanasi & $202(64,4)$ & - & - \\
\hline
\end{tabular}

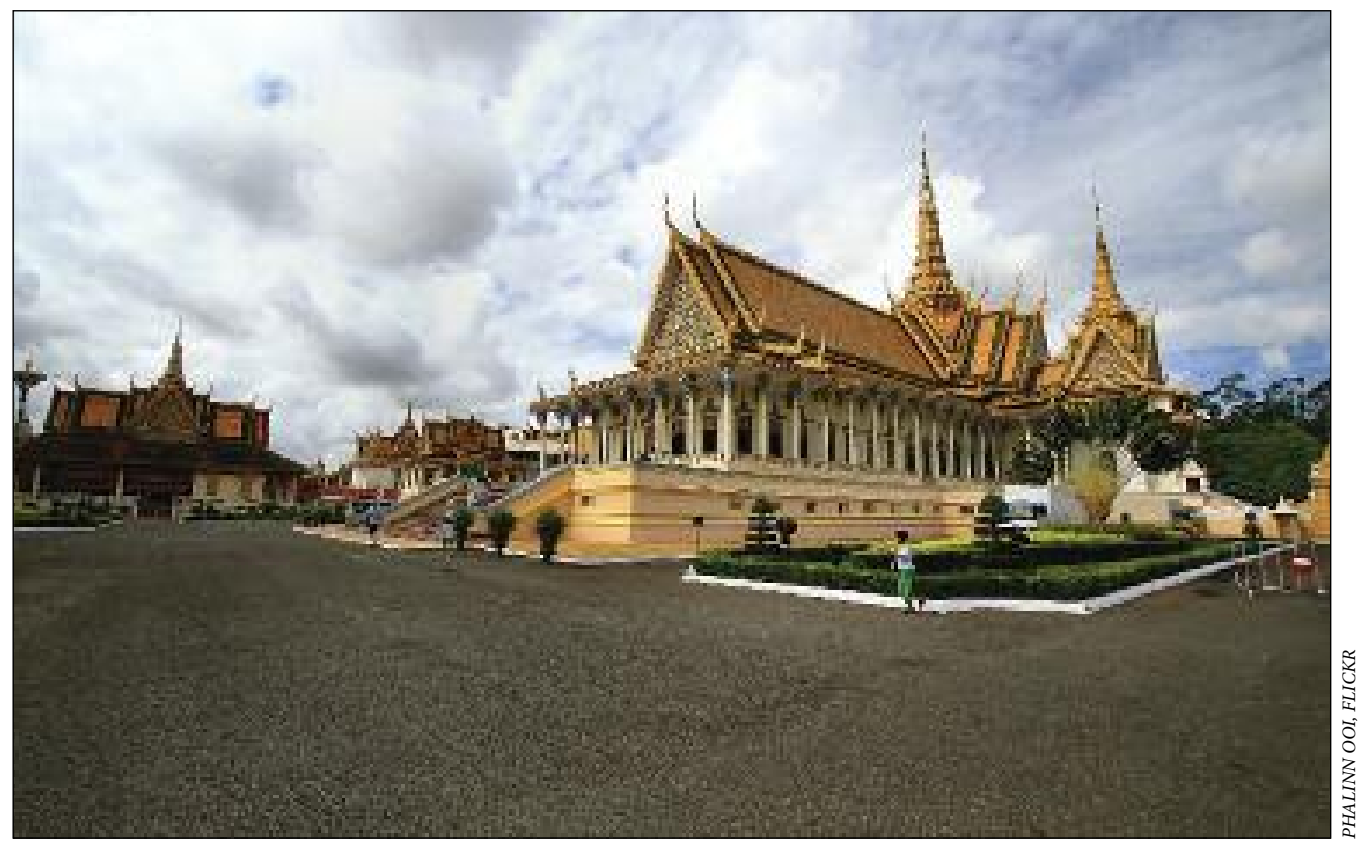

Slika 5: Budistični templji v kamboškem glavnem mestu Phnom Penhu, katerega ime se v slovenščini večinsko zapisuje v nasprotju $z$ veljavnimi pravopisnimi pravili. 
(59 zadetkov) enakovredno uveljavljata nova endonimska različica Sulawesi (98 zadetkov) in njen slovenski eksonim Sulavezi (82 zadetkov).

Drugače je z imenoma kitajskih mest Peking in Nanking, pri katerih se je z uvedbo pinjina pri prečrkovanju v mednarodni javnosti začela uveljavljati njuna endonimska imenska različica. Tako so se na primer v angleščini že povsem odrekli rabi nekdaj uveljavljenega eksonima Peking in ga nadomestili z izvirno mandarinsko imensko obliko Beijing, pa tudi eksonimov Nanking in Kanton, ki sta ju nadomestila endonima Nanjing oziroma Guangzhou. Tudi v slovenščini zadnja dva eksonima postopoma odmirata, medtem ko raba eksonima Peking ostaja v trdni rabi (Dobrovoljc 2017c). V prvem slovenskem atlasu sveta Atlantu (1869-1877) ga je uporabil že njegov redaktor Matej Cigale (Kladnik 2005b), eksonim pa se še vedno uporablja tudi v večini drugih pomembnejših jezikov (Preglednica eksonimov 2014). Podobno prilagajanje pinjinskemu zapisu je opazno tudi v rabi imena zahodnokitajske avtonomne pokrajine Sinkiang. To eksonimsko imensko različico se uporablja le še v slabi petini njenih navedb v Gigafidi (62 zadetkov), v preostali večini pa je že v rabi njena endonimska, s pinjinom prečrkovana imenska različica Xinjiang (263 zadetkov).

Zaradi množičnega spreminjanja imen v Mjanmaru in pomanjkanja seznamov s prečrkovanimi tamkajšnjimi zemljepisnimi imeni je njihova ustrezna raba zelo otežena; tudi v uglednih atlasih sveta se zato na ozemlju Mjanmara namesto endonimov praviloma uporabljajo angleški eksonimi. Težavna je tudi raba imena največjega mesta v državi in do novembra 2005 njene prestolnice, ki se je do leta 1989 $\mathrm{v}$ angleščini imenovalo Rangoon, po spremembi imena pa je postalo Yangon. Temu sta se prilagodila tudi slovenska eksonima Rangun oziroma Jangon. Prvi ima v Gigafidi 175 zadetkov, drugi 155. Kljub temu je še najpogostejša raba endonima Yangon (251 zadetkov), o težavnosti pravilnega zapisa tega imena pa govorijo številne druge v Gigafidi zabeležene imenske različice: Rangoon (39 zadetkov), Rangon (2), Jangun (33), Yangun (6) in Yangoon (7). Uvedba novega glavnega mesta ni težavnosti ustrezne rabe prav nič olajšala. Njegova endonimska različica, prečrkovana v angleščino, se imenuje Naypyidaw, uradno

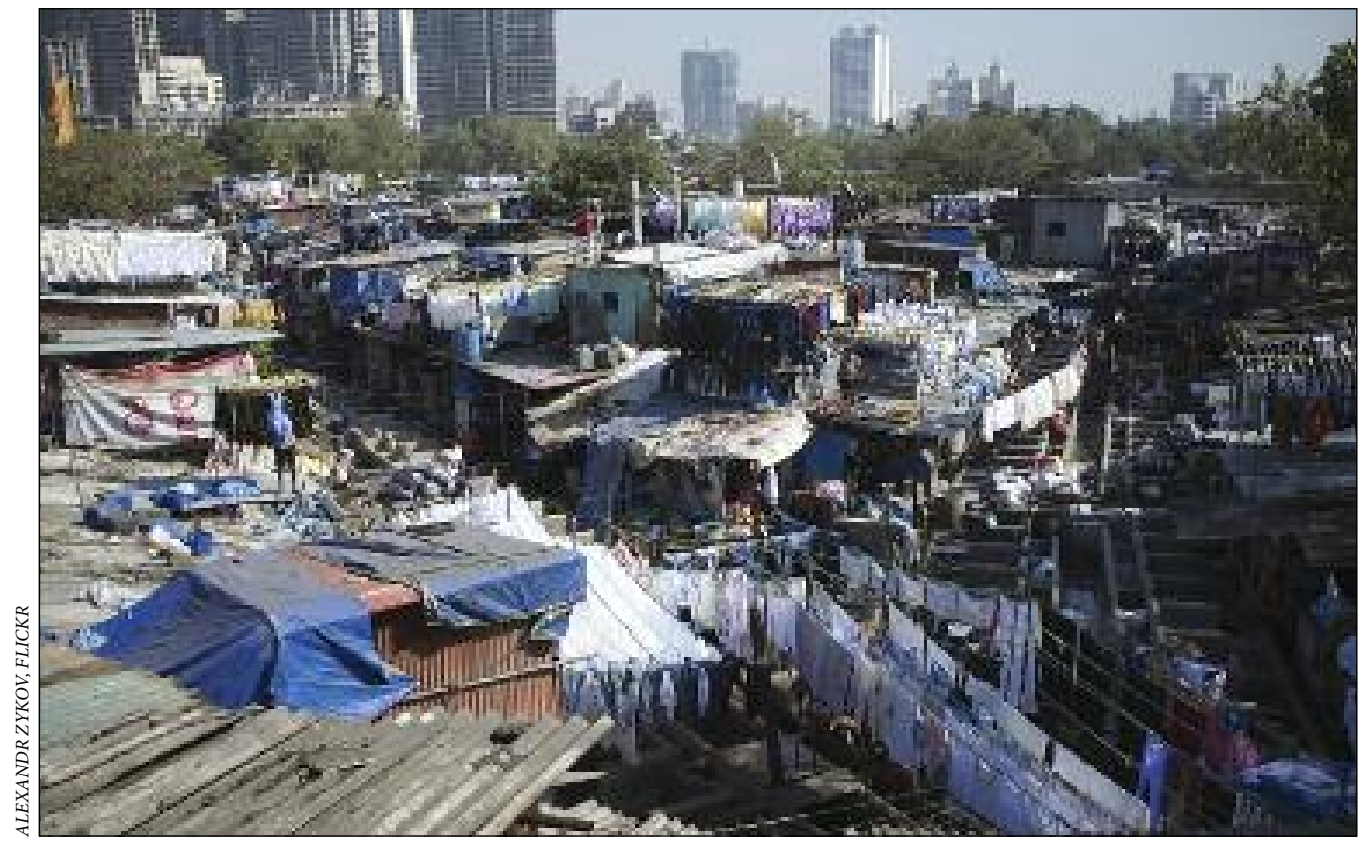

Slika 6: Značilen kontrast med barakarskim naseljem in sodobnimi stanovanjskimi stolpnicami $v$ zahodnoindijskem velemestu Mumbaju. 
prečrkovana Nay Pyi Taw, znani sta tudi različici Naypyitaw in Nepranytau (medmrežje 2). Zapis v Jezikovni svetovalnici (Dobrovoljc 2017b) priporoča, da se v slovenščini ime skladno z izgovorom podomači kot Nejpjido ali Nepjido, čemer pritrjujejo tudi poimenovanja v ruščini (Heǔnьuдo, prečrkovano Nejpido), srbščini (Hejnjudo, prečrkovano Nejpido) in češčini (Neipyijto, Nepjito, Nepyito).

Precej lažja je raba imen za največje in tretje največje mesto v Turčiji (preglednica 8). Za obe imamo uveljavljeni slovenski imeni, pri čemer si ime Carigrad tradicionalno delimo z drugimi južnoslovanskimi jeziki, ime Smirna pa izhaja iz grškega imena $\Sigma \mu v ́ \rho v \eta$, prečrkovano Smýrni, ki naj bi nastalo iz izraza smurna v pomenu 'mirta' (Preglednica eksonimov 2014).

Obe imeni spadata med naša najstarejša poimenovanja tujih mest. Medtem ko raba imena Smirna polagoma zamira in ima vse bolj arhaično konotacijo, je raba imena Carigrad še vedno zelo živa (Dobrovoljc 2013a), čeprav je v preostalih južnoslovanskih jezikih že dodobra utonila v pozabo. Arhaično konotacijo imata njegovi stari imenski različici Bizanc in Konstantinopel, medtem ko je ime Istanbul alternativni eksonim, nastal na podlagi izvirnega turškega imena İstanbul. Poleg tradicije proti njegovi rabi govori tudi večja možnost neustrezne rabe, kar potrjuje kar 286 Gigafidinih zapisov napačne imenske različice Istambul.

Težavna raba eksonimov je povezana tudi z ustreznim poimenovanjem mest v osamosvojenih državah na ozemlju nekdanje Sovjetske zveze, kjer je bil pred njenim razpadom sporazumevalni jezik ruščina. Zato so bile tudi v njih v prevladujoči rabi ruske imenske različice, ki so $\mathrm{z}$ nadaljnjo rabo

Preglednica 8: Pogostnost zapisov imenskih različic največjega in tretjega največjega turškega mesta v jezikovnem korpusu Gigafida (2017).

\begin{tabular}{lclclc}
\hline slovensko ime & $\begin{array}{c}\text { število navedb } \\
\text { (delež v \%) }\end{array}$ & $\begin{array}{l}\text { alternativni } \\
\text { eksonim }\end{array}$ & $\begin{array}{c}\text { število navedb } \\
\text { (delež v \%) }\end{array}$ & napačno ime & število navedb \\
\hline Carigrad & $7593(57,3)$ & Istanbul & $5649(42,7)$ & Istambul & 286 \\
\hline Smirna & $173(14,5)$ & Izmir & $1020(85,5)$ & - & - \\
\hline
\end{tabular}

Preglednica 9: Pogostnost zapisov različic imen nekaterih mest na ozemljih držav, ki so se osamosvojile po razpadu Sovjetske zveze, v jezikovnem korpusu Gigafida (2017).

\begin{tabular}{lclclc}
\hline $\begin{array}{l}\text { tradicionalni } \\
\text { slovenski } \\
\text { eksonim }\end{array}$ & $\begin{array}{c}\text { število navedb } \\
\text { (delež v \%) }\end{array}$ & $\begin{array}{l}\text { sodobnemu } \\
\text { endonimu } \\
\text { prilagojen } \\
\text { eksonim }\end{array}$ & $\begin{array}{c}\text { število navedb } \\
\text { (delež v \%) }\end{array}$ & $\begin{array}{l}\text { morebitna tretja } \\
\text { imenska različica } \\
\text { (endonim } \\
\text { ali napačno } \\
\text { zapisano ime) }\end{array}$ & število navedb \\
\hline Alma Ata & $42(35,3)$ & Almati & $77(64,7)$ & Almaty & As \\
Ašhabad & $38(33,9)$ & Ašgabat & $74(66,1)$ & Asgabad & 2 \\
Dnepropetrovsk & $60(58,8)$ & Dnipropetrovsk & $42(41,2)$ & - & - \\
Harkov & $278(95,2)$ & Harkiv & $14(4,8)$ & - & - \\
Kijev & $8569(100,0)$ & Kijiv & $2(0,0)$ & - & - \\
Kišinjov & $366(70,4)$ & Kišinjev & $154(29,6)$ & Kišinev & - \\
Lvov (slika 7) & $549(87,8)$ & Lviv & $72(12,2)$ & - & - \\
Taškent & $545(100,0)$ & Toškent & $0(0,0)$ & - & - \\
Vitebsk & $118(99,2)$ & Vicebsk & $1(0,8)$ & - & - \\
Zaporožje & $1037(100,0)$ & Zaporižja & $0(0,0)$ & - & - \\
\hline
\end{tabular}


po osamosvojitvi in potiskanju ruščine $\mathrm{v}$ drugi plan postale slovenski eksonimi. Odpira se dilema, ali naj v slovenščini po osamosvojitvi teh držav uporabljamo izvirna imena v njihovih uradnih jezikih ali naj, vsaj v primerih večjih in glavnih mest, ohranimo njihove iz ruščine izpeljane eksonime. Ta dilema se nakazuje tudi v pogostosti rabe imen nekaterih tamkajšnjih mest, kot jih beleži Gigafida (preglednica 9).

Zaradi tradicionalne uveljavljenosti ruskih imenskih različic ne preseneča, da iz njih izpeljani slovenski eksonimi praviloma prevladujejo. Izjemi sta imeni največjega kazahstanskega mesta Almati (izvirno Almaty), ki se je do leta 1993 imenovalo Alma-Ata, in turkmenistanskega glavnega mesta Ašgabat (izvirno Aşgabat), pri katerem se je prevladujoči eksonim oprl na njegovo turkmensko izvirno obliko. V bližnjih državah Ukrajini, Belorusiji in Moldaviji je opazna močna prevlada eksonimov, nastalih na podlagi ruskih imen. Edina izjema je ime mesta Dnepropetrovsk, ki se postopoma umika eksonimu Dnipropetrovsk, izpeljanemu iz ukrajinščine.

Obravnavani tematiki je posvečen tudi zapis v Jezikovni svetovalnici (Torkar 2012). V njem je svetovalec med drugim zapisal: "... Od krajev v Ukrajini sta v slovenskem knjižnem jeziku najbolj trdno zasidrana Lvov in Kijev. Moje mnenje je, da smemo z vso pravico ostati pri teh oblikah in da nam tega nihče ne more očitati ali celo prepovedati. /.../ Pri vprašanju imen ukrajinskih mest Kijev, Harkov, Lvov, Zaporožje, Černobil in verjetno še katerega so se sestavljavci pravil - za ta del je bilo odločilno mnenje prof. Jakopina - ozirali predvsem na tradicionalno rabo ruskih oblik v slovenskem jezikovnem prostoru. /.../ Rabe oblik krajevnih imen $v$ slovenščini ni smiselno povezovati z razumevanjem oz. upoštevanjem statusa ukrajinščine kot državnega jezika, ker je to avtonomno slovensko vprašanje ...«.

Med naselbinskimi eksonimi, ki v slovenščini nezadržano odmirajo, so predvsem tisti z območja Angloamerike (preglednica 10). Nekoč so se zaradi pomembnosti Philadelphie za zgodovino Združenih držav in Chicaga za mednarodno delavsko gibanje občutno pogosteje uporabljali.

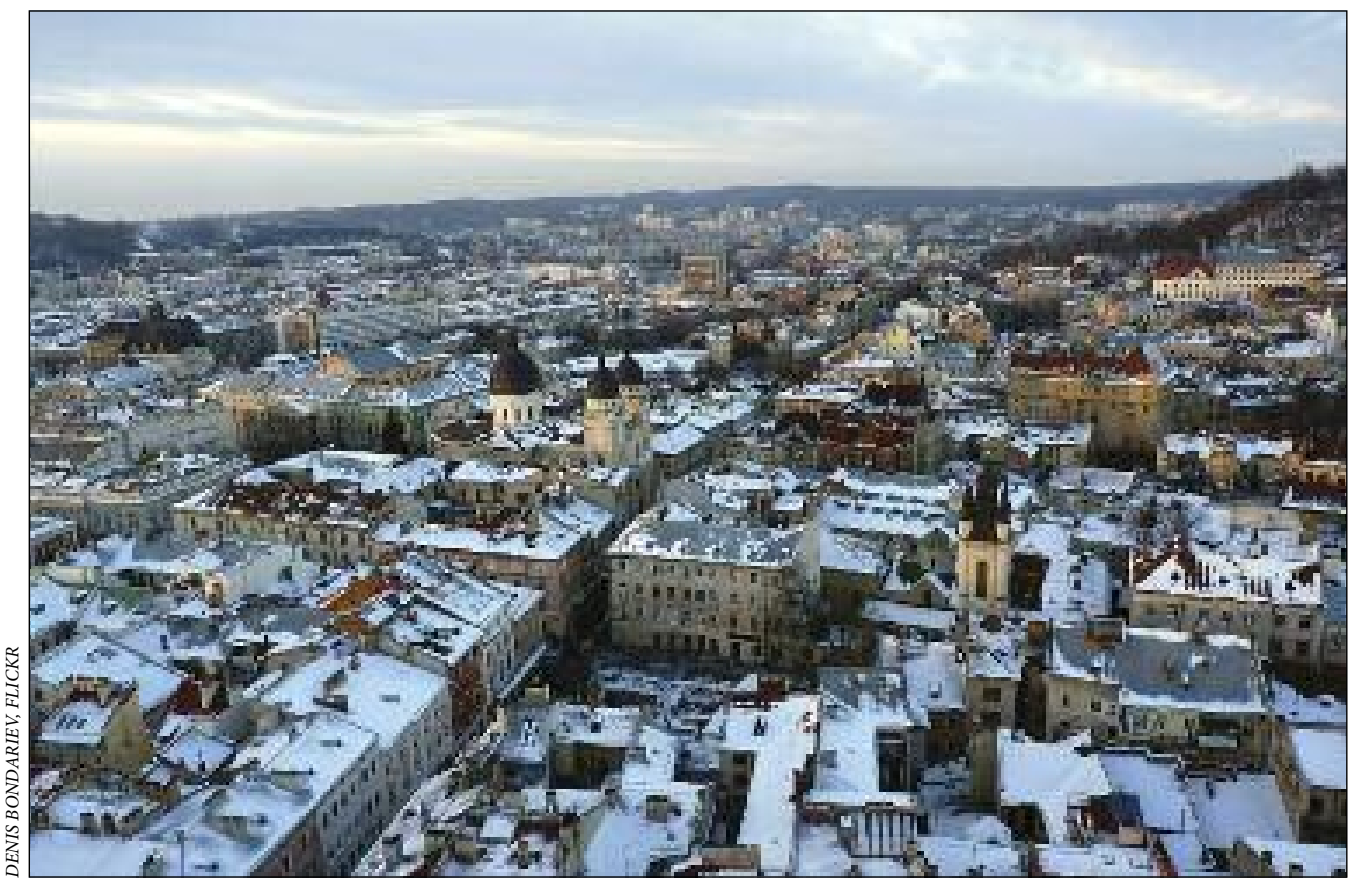

Slika 7: Panorama Lvova, ukrajinskega mesta, ki je bilo v okviru Avstro-Ogrske del naše širše domovine, zato je njegovo takratno slovensko ime pri nas še vedno trdno uveljavljeno. 
Eksonima Čikago in Filadelfija imata vsega nekaj odstotkov navedb od vseh zapisov imen obeh mest. Opozoriti velja tudi na njuna napačna zapisa Chichago in Philadelphija, pri čemer je slednji celo številčnejši od njegove eksonimske različice. Poleg obeh nekdaj pogosteje rabljenih eksonimov smo v Gigafidi našli še posamezne zapise podomačenih imen za mesti New York (Novi Jork (23 zadetkov), Novi York (11 zadetkov)) in New Orleans (Novi Orleans (3 zadetki)).

Ime Washington (slika 8) v bistvu ni pravi eksonim, saj se od uradnega izvirnega imena razlikuje le po izpustitvi pristavka D.C. Ta označuje njegovo lego v Kolumbijskem okrožju (District of Columbia), po čemer ga je mogoče ločiti od zvezne države Washington na severozahodu Združenih držav Amerike. Z zapisom pristavka D.C. imamo v slovenščini težave, kar kaže raznolikost zaznanih navedb v Gigafidi. Najštevilčnejša je Washington DC (129 zadetkov), sledijo pa Washington D.C. (96 zadetkov), Washington, DC (64 zadetkov) in uradno ime Washington, D.C. (62 zadetkov).

Preglednica 10: Pogostnost zapisov različic imen nekaterih mest v Združenih državah Amerike, za katera so se uveljavili slovenski eksonimi, v jezikovnem korpusu Gigafida (2017).

\begin{tabular}{lclclc}
\hline $\begin{array}{l}\text { slovenski } \\
\text { eksonim }\end{array}$ & $\begin{array}{c}\text { število navedb } \\
(\text { delež v \%) }\end{array}$ & endonim & $\begin{array}{c}\text { število navedb } \\
\text { (delež v \%) }\end{array}$ & $\begin{array}{l}\text { morebitna tretja } \\
\text { imenska različica }\end{array}$ & število navedb \\
\hline Čikago & $254(1,6)$ & Chicago & $15.885(98,4)$ & Chichago & 115 \\
Filadelfija & $651(5,8)$ & Philadelphia & $10.590(94,2)$ & Philadelphija & 829 \\
Washington & $47.966(99,7)$ & Washington DC & $129(0,3)$ & Vašington & 8 \\
\hline
\end{tabular}

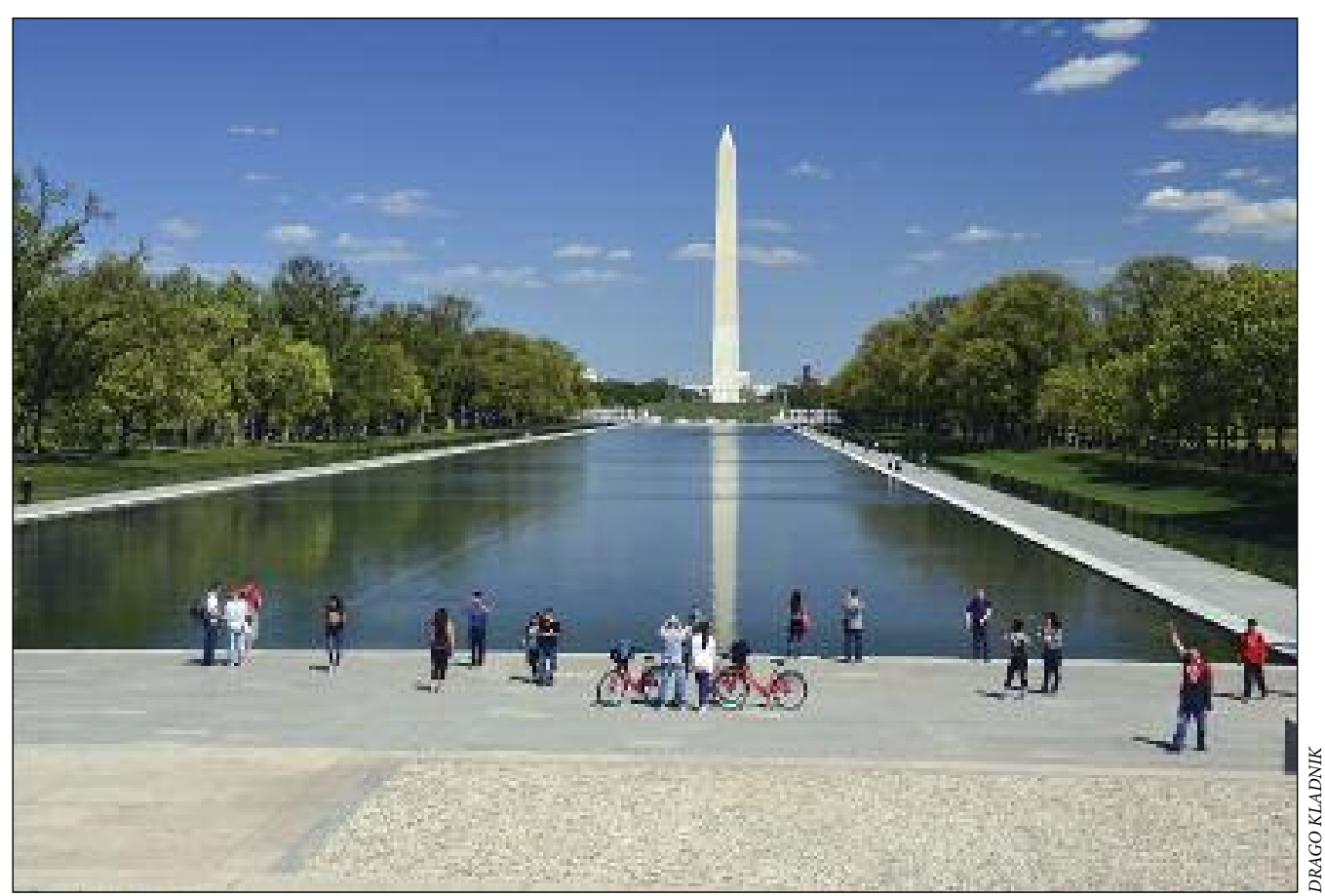

Slika 8: Glavno mesto Združenih držav Amerike je Washington. Na fotografiji je pogled izpred Lincolnovega spomenika na Washingtonov slavolok sredi tamkajšnjega prostranega spominskega parka. 
Tako kot obravnavo imen držav tudi obravnavo imen mest končujemo s problematičnimi predložnimi zvezami. Gre predvsem za slovenske eksonime mest ob vodotokih, pri katerih se je v preteklosti uveljavila raba manj ustreznega predloga na namesto ustreznejšega $o b$ (preglednica 11).

Pripisati jo gre nedomišljenemu, dobesednemu prevajanju predlogov, ki jih vsebujejo izvirna imena. Prepričani smo, da je predlog na ustrezen le v primerih, ko je določena naselbina dejansko na rečnem otoku, tako kot je v primeru Kostanjevice na Krki. Sicer je ustrezneje uporabiti predlog ob, ki natančno izrazi, da je ta naselbina na enem od bregov ali na obeh bregovih reke.

Čeprav je v večini primerov še vedno zaznavna prevladujoča raba manj primerne predložne zveze, se raba ustreznejše zagotovo čedalje bolj uveljavlja, v primeru koroškega mesta Šentvid ob Glini (nemško Sankt Veit an der Glan) pa je že prevladala.

Preglednica 11: Pogostnost rabe bolj in manj primernih predložnih zvez v nekaterih eksonimih, kot jih beleži jezikovni korpus Gigafida (2017).

\begin{tabular}{lclc}
$\begin{array}{l}\text { eksonimska različica } \\
\text { s predlogom } o b\end{array}$ & $\begin{array}{c}\text { število navedb } \\
(\text { delež v \%) }\end{array}$ & $\begin{array}{l}\text { eksonimska različica } \\
\text { s predlogom } n a\end{array}$ & $\begin{array}{c}\text { število navedb } \\
\text { (delež v \%) }\end{array}$ \\
\hline $\begin{array}{l}\text { Frankfurt ob Majni (slika 9) } \\
\text { Frankfurt ob Odri }\end{array}$ & $40(25,0)$ & Frankfurt na Majni & $120(75,0)$ \\
$\begin{array}{l}\text { Rostov ob Donu } \\
\text { Šentvid ob Glini }\end{array}$ & $28(35,9)$ & Frankfurt na Odri & $50(64,1)$ \\
\hline
\end{tabular}

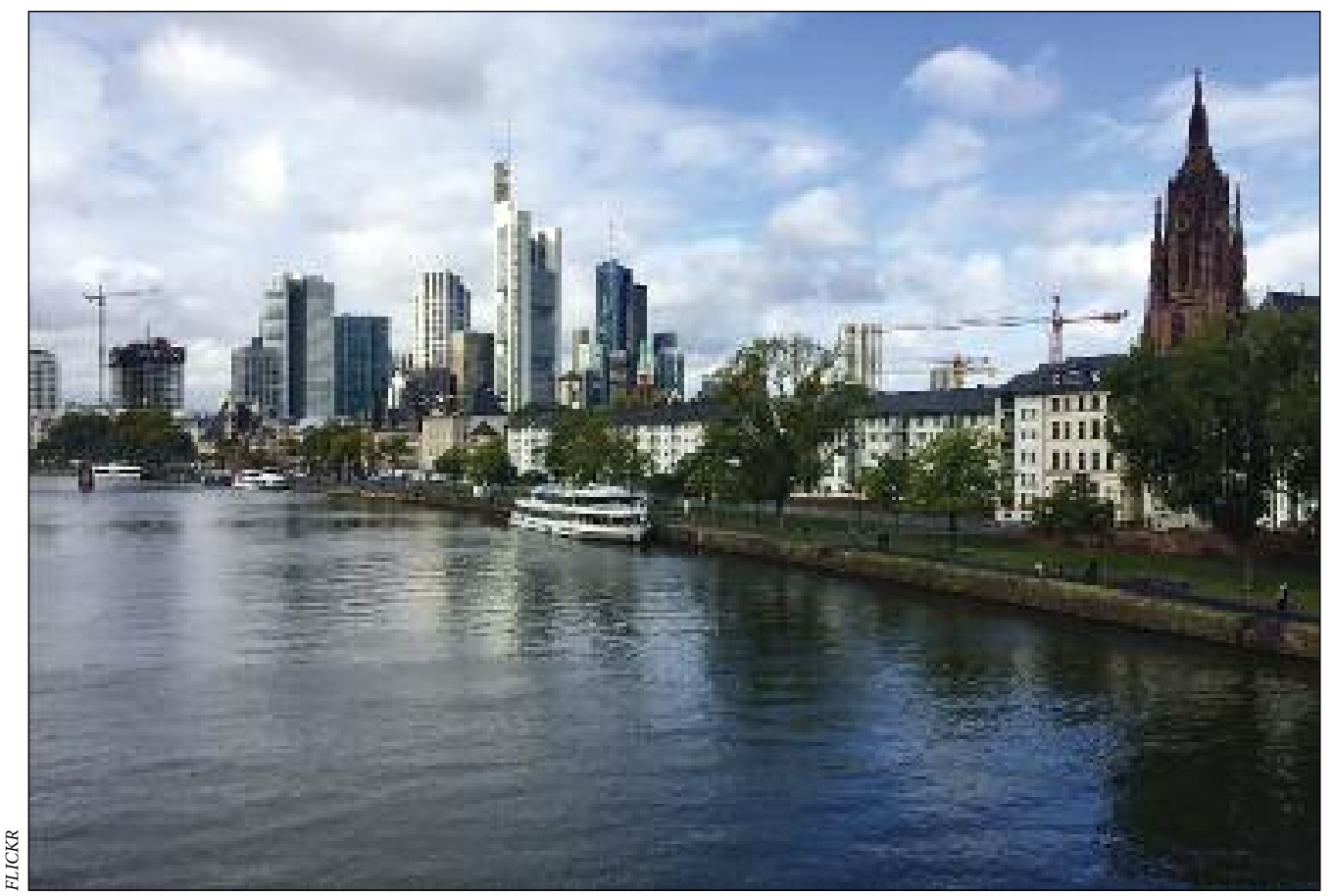

Slika 9: Nemško mesto Frankfurt ob Majni je pomembno finančno središče. Zraslo je na obeh bregovih reke Majne, desnega pritoka Rena. 


\section{Sklep}

Pričakovati je, da bo z novim slovenskim pravopisom raba zemljepisnih imen za splošno javnost olajšana, kar velja še posebej zaradi načrtovanih sprememb pravil pri rabi velike in male začetnice. Ta odpravljajo izjeme pri rabi velike začetnice v večbesednih naselbinskih imenih $z$ občnoimenskimi sestavinami mesto, vas, selo, trg in naselje, ki se naj bi po novem, tako kot v večini evropskih jezikov, pisala $z$ veliko začetnico. Prav tako naj bi se $z$ veliko začetnico pisala večbesedna zemljepisna imena mestnih delov, v obeh primerih pa bodo še vnaprej izjeme le morebitni neprvi oziroma vmesni predlogi (na primer Nova Vas pri Ptuju). Pri večbesednih nenaselbinskih imenih bo predvidoma z veliko začetnico vselej zapisana prva imenska sestavina, začetnica drugih sestavin pa se bo ravnala po tem, ali ima ta občni značaj ali je lastno ime. $V$ prvem primeru bo zapisana $\mathrm{z}$ malo začetnico, $\mathrm{v}$ drugem pa $\mathrm{z}$ veliko.

Mednarodnim priporočilom bodo v večji meri prilagojena tudi pravila o prevzemanju tujih besed v slovenščino, kar pomeni, da bo skladno z upoštevanjem pravil mednarodnih latiničnih prečrkovanj $\mathrm{v}$ manjši meri predvideno zdaj skoraj zapovedano domačenje lastnih imen, v izvirni obliki zapisanih $\mathrm{v}$ nelatiničnih pisavah ali ideogramih.

Nekatera lastna imena, zemljepisna niso nikakršna izjema (tako se je na primer po pokrajini Kras mednarodno uveljavil pojem kras oziroma karst za pokrajine iz karbonatnih kamnin ter z značilnimi površinskimi in podzemeljskimi pojavi), se po določenem času polastnoimenijo in dobijo predmetni pomen. $Z$ apelativizacijo izgubijo značilno identifikacijsko oziroma individualizacijsko vlogo, kar vpliva na njihov zapis z malo začetnico, pogosto jih tudi pisno prilagodimo slovenščini (Dobrovoljc 2012a, 32-33).

Za zdaj lahko iz zapisanega sklenemo, da je ustrezna raba zemljepisnih imen razmeroma zapletena in zahteva usklajenost jezikoslovcev, geografov, kartografov in drugih vpletenih strokovnjakov. Pomemben prispevek k poenotenju rabe in s tem manjši zmedi je standardizacija zemljepisnih imen,

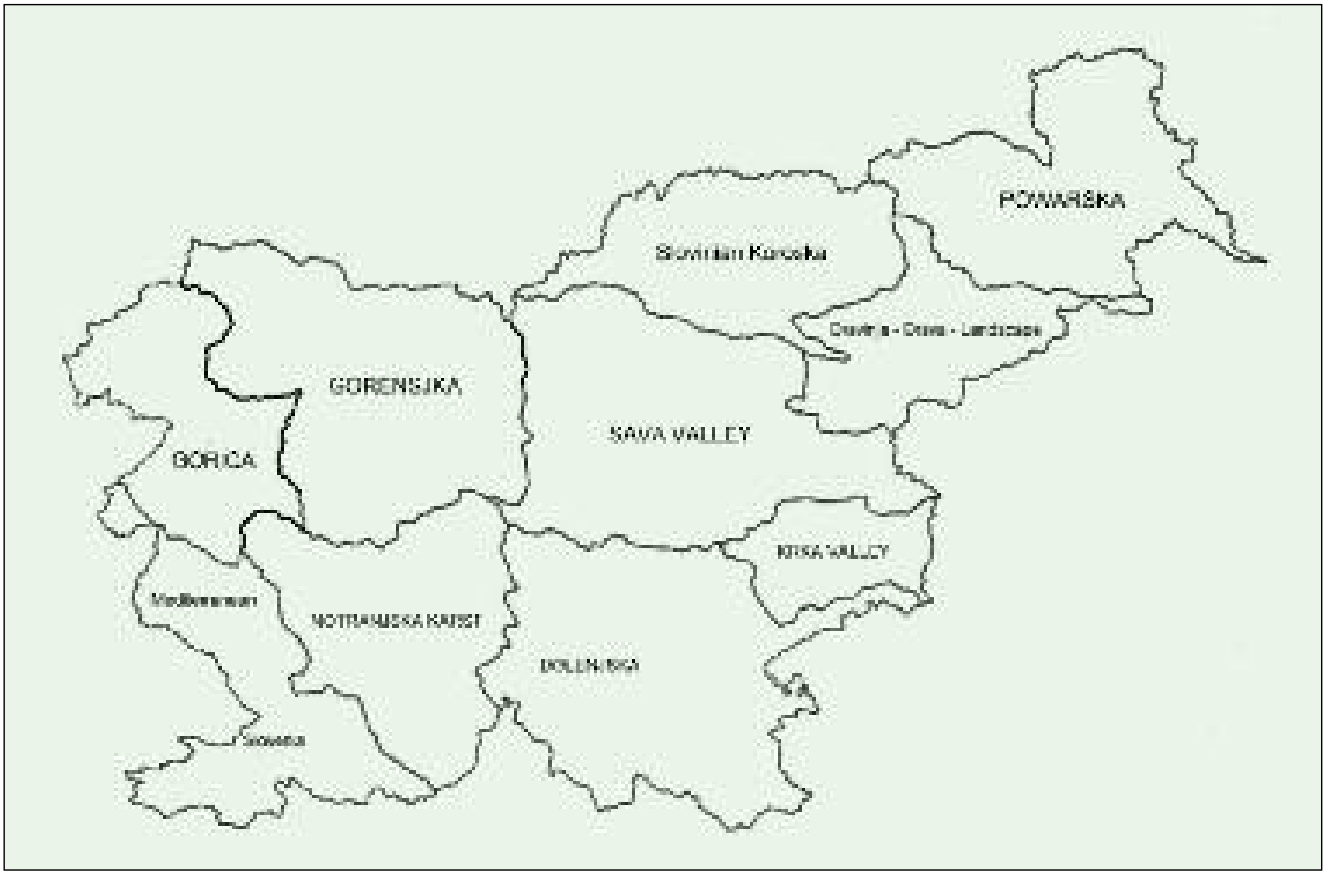

Slika 10: Regionalizacija s poimenovanji regij Slovenije, kot so si jih v okviru evropskega projekta zamislili strokovnjaki nizozemskega vodilnega partnerja (Brink van den 2014/2015). 
pri čemer smo v Sloveniji zaradi pomanjkanja sredstev za ta namen za zdaj naredili le skromne korake. Pred standardizacijo je namreč potreben temeljit jezikovni in pomenski pretres posameznih imen.

Ker razen za imena držav, naselij na ozemlju Republike Slovenije ter pomembnejših slovenskih pokrajin, gorovij, vrhov, vodotokov in jezer standardizacija še ni bila opravljena, je ob snovanju novega slovenskega pravopisa treba poskrbeti za ustrezen nabor pojmov za njegov slovarski del, pa tudi za ustrezne ponazoritvene primere $\mathrm{v}$ pravilih. Vključena naj bi bila vsa imena neodvisnih držav in najpomembnejših odvisnih ozemelj ter vsa glavna, vključno $\mathrm{z}$ imeni njihovih prebivalcev, največja mesta, sistematizirana imena upravnih enot, največja jezera, najdaljše reke, najvišji in najmogočnejši slapovi, največja pogorja in najvišji vrhovi, največji otoki, glavni polotoki (denimo po deset v svetovnem merilu za vsak pojav in vsa bolj znana pri nas), a tudi imena, ki so pridobila občnoimenski značaj, na primer Angora (zdaj Ankara), Florenca (zdaj Firence), Jersey, Shetlantski otoki, Solnograd (zdaj Salzburg).

Če ne bomo sistematično skrbeli za ustrezno rabo naših in podomačenih tujih zemljepisnih imen, se bodo v zvezi z njimi še vnaprej pojavljale nejasnosti in nepoenotena raba, še mnogo bolj zanimivo pa utegne dogajanje postati ob morebitnem vpletanju tujcev. To slutnjo lahko podkrepimo z resničnim dogajanjem, ko so v okviru evropskega projekta, ki so ga vodili na nizozemski univerzi v Wageningenu, prek regionalizacij in poimenovanj značilnih pokrajin skušali dognati značaj evropskih pokrajin (Brink van den 2014/2015). Nizozemski sodelavci so se glede Slovenije obrnili na Geografski inštitut Antona Melika ZRC SAZU, zato smo jim posredovali našo naravnogeografsko regionalizacijo (Kladnik 1996, 153-156; Fridl s sodelavci 1998, 125), zemljevid nekdanjih avstrijskih dežel (Gabrovec in Rajšp 1998, 33) in zemljevid s predvideno členitvijo Slovenije na 12 pokrajin (Vrišer 1999, 121-122). Ker se jim z vidika vpetosti Slovenije v širši evropski prostor nobena od naših členitev ni zdela primerna, prepričali pa jih niso niti naši pomisleki, da poenotenje naravnogeografske in družbenogeografske členitve ozemlja naše države ni možno, so se na podlagi prejetih gradiv v novoletnih dneh odločili pripraviti »inovativno « lastno členitev. Z njo so nas seznanili v prvih dneh leta 2015 ter v nas zasejali resen dvom o znanstveni in etični neoporečnosti v splošnem sicer zelo čislanih zahodnoevropskih strokovnjakov. Rezultat je viden na sliki 10. Opozarjamo predvsem na semantično »enotnost « imenske ravni in geografsko »stvarnost « na novo »skovanih « pokrajin, pri čemer seveda ne moremo prezreti izjemne površnosti vodilnega partnerja.

Zahvala: Prispevek temelji na raziskovalnem programu Geografija Slovenije (P6-0101), ki ga financira Javna agencija za raziskovalno dejavnost Republike Slovenije.

\section{Viri in literatura}

Berk, S. 2001: O tujejezičnih ustreznicah za slovenska zemljepisna imena. Geografski vestnik 73-1.

Bizjak, A. 2012: Pisno podomačevanje novejših prevzetih besed v slovenščini. Pravopisna stikanja: Razprave o pravopisnih vprašanjih. Ljubljana.

Brink van den, T. 2014/2015: Request for participation for our project on the European Landscape Character Assessment through the lens of unique toponyms. Elektronska korespondenca z Dragom Kladnikom.

Dobrovoljc, H. 2004: Pravopisje na Slovenskem. Lingua Slovenica. Ljubljana.

Dobrovoljc, H. 2012a: Pisanje imen izdelkov in znamk. Pravopisna stikanja: Razprave o pravopisnih vprašanjih. Ljubljana.

Dobrovoljc, H. 2012b: Pisanje začetnice v predložnih lastnih imenih. Pravopisna stikanja: Razprave o pravopisnih vprašanjih. Ljubljana.

Dobrovoljc, H. 2013a: Dve imeni enega mesta: Carigrad in Istanbul. Jezikovna svetovalnica. Medmrežje: http://isjfr.zrc-sazu.si/sl/svetovalnica/dve-imeni-enega-mesta-carigrad-in-istanbul\#v (25. 11.2017).

Dobrovoljc, H. 2013b: »Hošiminh « proti »Ho Ši Minh«: dve lastni imeni? Jezikovna svetovalnica. Medmrežje: http://isjfr.zrc-sazu.si/sl/svetovalnica/hosiminh-proti-ho-si-minh-dve-lastni-imeni\#v (25.11.2017). 
Dobrovoljc, H. 2013c: Nadomestna in skrajšana zemljepisna imena - „Obala«. Jezikovna svetovalnica. Medmrežje: http://isjfr.zrc-sazu.si/sl/svetovalnica/nadomestna-in-skrajsana-zemljepisna-imenaobala\#v (25.11.2017).

Dobrovoljc, H. 2013d: Prevedena večbesedna naselbinska imena in raba začetnice. Jezikovna svetovalnica. Medmrežje: http://isjfr.zrc-sazu.si/sl/svetovalnica/prevedena-vecbesedna-naselbinska-imena-inraba-zacetnice\#v (28.11.2017).

Dobrovoljc, H. 2014a: Izjeme pri domačenju zemljepisnih imen. Jezikovna svetovalnica. Medmrežje: https://svetovalnica.zrc-sazu.si/topic/86/izjeme-pri-domačenju-krajevnih-imen (24.11.2017).

Dobrovoljc, H. 2014b: Podomačevanje tujih zemljepisnih imen: imena krajev. Jezikovna svetovalnica. Medmrežje: http://isjfr.zrc-sazu.si/sl/svetovalnica/podomacevanje-tujih-zemljepisnih-imen-imenakrajev\#v (24.11.2014).

Dobrovoljc, H. 2015a: Podomačevanje imena »Liechtenstein«. Jezikovna svetovalnica. Medmrežje: https://svetovalnica.zrc-sazu.si/topic/1033/podomačevanje-imena-liechtenstein (25.11.2017).

Dobrovoljc, H. 2015b: Slovenjenje krajevnih imen: splošno. Jezikovna svetovalnica. Medmrežje: https://svetovalnica.zrc-sazu.si/topic/855/slovenjenje-krajevnih-imen-splošno (25.11.2017).

Dobrovoljc, H. 2015c: Slovenska ustreznica imena »Mauritius« je »Mavricij«. Jezikovna svetovalnica. Medmrežje: https://svetovalnica.zrc-sazu.si/topic/841/slovenska-ustreznica-imena-mauritius-jemavricij (24.11.2017).

Dobrovoljc, H. 2017a: »Mavricij« in »Papua Nova Gvineja«. Jezikovna svetovalnica. Medmrežje: https://svetovalnica.zrc-sazu.si/topic/2025/mavricij-in-papua-nova-gvineja (24.11.2017).

Dobrovoljc, H. 2017b: Glavno mesto v Mjanmarju. Jezikovna svetovalnica. Medmrežje: https://svetovalnica.zrc-sazu.si/topic/2006/glavno-mesto-v-mjanmarju (26.11.207).

Dobrovoljc, H. 2017c: Zakaj se glavnemu mestu Kitajske v slovenščini reče Peking? Jezikovna svetovalnica. Medmrežje: https://svetovalnica.zrc-sazu.si/topic/990/zakaj-se-glavnemu-mestu-kitajske-vslovenščini-reče-peking (25.11.2017).

Dobrovoljc, H., Jakop, N. 2011: Sodobni pravopisni priročnik med normo in predpisom. Ljubljana.

Dobrovoljc, H., Jakop, N. (ur.) 2012: V iskanju soglasja. Pravopisna stikanja: Razprave o pravopisnih vprašanjih. Ljubljana.

Dobrovoljc, H., Lengar Verovnik, T. (ur.) 2015: Pravopisna razpotja: Razprave o pravopisnih vprašanjih. Ljubljana.

Dobrovoljc, H., Weiss, P. 2016: »Saudova« ali »Saudska« Arabija? Jezikovna svetovalnica. Medmrežje: https://svetovalnica.zrc-sazu.si/topic/1737/saudova-ali-savdska-arabija (24.11.2017).

Dobrovoljc, H., Weiss, P., Lengar Verovnik, T., Snoj, M. 2016: Ali slovenimo ime krajev »Biograd na Moru« in »Filip i Jakov«. Jezikovna svetovalnica. Medmrežje: https://svetovalnica.zrc-sazu.si/topic/ 1621/ali-slovenimo-ime-krajev-biograd-na-moru-in-filip-i-jakov (25.11.2017).

Fridl, J., Kladnik, D., Orožen Adamič, M., Perko, D. (ur.) 1998: Geografski atlas Slovenije: Država v prostoru in času. Ljubljana.

Furlan, M. 2003: Slovenska imena držav v Slovenskem pravopisu in standardizacija SIST ISO 3166: 1996 (razlike). Tipkopis. Ljubljana.

Furlan, M., Gložančev, A., Šivic-Dular, A. 2000: Pravopisna ustreznost zapisa lastnoimenskega gradiva v registru zemljepisnih imen in registru prostorskih enot. Geografski vestnik 72-1.

Furlan, M., Gložančev, A., Kladnik, D., Perko, D., Šivic-Dular, A. 2008: Imenik zemljepisnih imen Državne pregledne karte Republike Slovenije v merilu $1: 250.000=$ Gazetter of the National general map of the Republic of Slovenia at the scale $1: 250,000$. Državna pregledna karta Republike Slovenije 1:250.000: standardizirana slovenska zemljepisna imena = National general map of the Republic of Slovenia 1:250,000: standardized Slovene geographical names. Ljubljana.

Gabrovec, M., Perko, D. 1997: Imenik uradnih imen naselij v Sloveniji. Elaborat, Geografski inštitut Antona Melika ZRC SAZU. Ljubljana. 
Gabrovec, M., Rajšp, V. 1998: Avstrijske dežele leta 1914: zemljevid. Geografski atlas Slovenije: Država $\mathrm{v}$ prostoru in času. Ljubljana.

Gams, I. 1972: Za poenostavitev pravopisnih pravil: poročilo s posvetov o pisanju zemljepisnih imen (I. in II.). Naši razgledi (24.11. in 8.12.1972).

Gams, I. 1984: Prizadevanje Geografskega društva Slovenije za standardizacijo slovenskih lastnih geografskih imen. Zbornik radova savjetovanja o pitanjima standardizacije geografskih naziva u jezicima naroda i narodnosti SFRJ. Sarajevo.

Geršič, M. 2016a: Ledinska imena na kulturnih terasah. Geografski vestnik 88-2. DOI: https://doi.org/ 10.3986/GV88205

Geršič, M. 2016b: Slovenska pokrajinska imena kot dejavnik identitete. Doktorsko delo, Oddelek za geografijo Filozofske fakultete Univerze v Ljubljani. Ljubljana.

Geršič, M. 2017: Changing denotations of selected Slovenian choronyms. Acta geographica Slovenica 57-1. DOI: https://doi.org/10.3986/AGS.4600

Geršič, M., Kladnik, D. 2014: Street-name changes in Ljubljana. Place-Name Changes: Proceedings of the Symposion in Rome. Hamburg.

Geršič, M., Kladnik, D. 2015: Slovenian geographical names as exonyms. Confirmation of the Definitions: Proceedings of the $16^{\text {th }}$ UNGEGN Working Group on Exonyms Meeting. Hamburg.

Geršič, M., Kladnik, D. 2016: House names and field names as an important part of Slovenian cultural heritage: a case study of the Leše cadastral municipality, Upper Carniola, Slovenia. Nomina africana 30-1.

Geršič, M., Zorn, M. 2016: Odsev naravnih nesreč v zemljepisnih imenih - nekaj primerov iz Zahodnih Karavank in zahodnih Kamniško-Savinjskih Alp. Kronika 64-3.

Gigafida 2017. Medmrežje: http://www.gigafida.net/ (20.10.2017).

Horvat, M. 2015: Rodilniška oblika panonskih, štajerskih in belokranjskih krajevnih imen na -ci, -ovci/evci, -inci (tip Beltinci - iz Beltinec/Beltincev). Pravopisna razpotja: Razprave o pravopisnih vprašanjih. Ljubljana.

Jakop, N. 2012: Pisanje pridevnikov na -ov, -ev, -in iz lastnih imen. Pravopisna stikanja: Razprave o pravopisnih vprašanjih. Ljubljana.

Jemec Tomazin, M. 2012: Terminologija v slovenskem pravopisu. Pravopisna stikanja: Razprave o pravopisnih vprašanjih. Ljubljana.

Jezikovna svetovalnica 2017. Inštitut za slovenski jezik Frana Ramovša ZRC SAZU. Ljubljana. Medmrežje: https://svetovalnica.zrc-sazu.si/ (15. 10.2017).

Jordan, P. 2000: The importance of using exonyms - Pleading for a moderate and politically sensitive use. Mitteilungen des Bundesamtes für Kartographie und Geodäsie 19.

Jordan, P., Orožen Adamič, M., Woodman, P. (ur.) 2007: Exonyms and the International Standardisation of Geographical Names: Approaches towards the Resolution of an Apparent Contradiction. Wiener Osteuropa Studien 24. Wien.

Kadmon, N. 2000: Toponymy. The Lore, Laws and Language of Geographical Names. New York.

Kladnik, D. 1996: Naravnogeografske členitve Slovenije. Geografski vestnik 68.

Kladnik, D. 2001: Seznam tujih zemljepisnih imen v slovenskem jeziku. Medmrežje: http://www.gu.gov.si/ fileadmin/gu.gov.si/pageuploads/publikacije/arhiv_publik/seznam_tujih_zemljepisnih_imen.pdf (16. 10.2016).

Kladnik, D. 2005a: Geografov pogled na tuja zemljepisna imena. Geografski vestnik 77-2.

Kladnik, D. 2005b: Zemljepisna imena v Atlantu in njihov pomen za sodobno imenoslovje. Atlant, faksimilirana izdaja. Ljubljana.

Kladnik, D. 2006: Tuja zemljepisna imena v slovenskem jeziku; razvojni vidiki in problematika njihove rabe. Doktorsko delo, Oddelek za geografijo Filozofske fakultete Univerze v Ljubljani. Ljubljana.

Kladnik, D. 2007a: Podomačena tuja zemljepisna imena v slovenskih atlasih sveta. Geografija Slovenije 14. Ljubljana.

Kladnik, D. 2007b: Pogledi na podomačevanje tujih zemljepisnih imen. Georitem 2. Ljubljana. 
Kladnik, D. 2007c: Zgodovinski vidiki podomačevanja tujih zemljepisnih imen. Zgodovinski časopis 61, 3-4.

Kladnik, D. 2009a: Odprte dileme pomenske razmejitve izrazov endonim in eksonim. Geografski vestnik 81-1.

Kladnik, D. 2009b: Semantic demarcation of the concepts of endonym and exonym. Acta geographica Slovenica 49-2. DOI: https://doi.org/10.3986/AGS49206

Kladnik, D. 2012: Slovenian geography and geographical names. Geografski vestnik 84-1.

Kladnik, D., Bole, D. 2012: The life of Slovenian exonyms and their familiarity in the professional community. Acta geographica Slovenica 52-2. DOI: https://doi.org/10.3986/AGS52204

Kladnik, D., Ciglič, R., Hrvatin, M., Perko, D., Repolusk, P., Volk Bahun, M. 2013: Slovenski eksonimi. Geografija Slovenije 24. Ljubljana.

Kladnik, D., Crljenko, I., Čilaš Šimpraga, A., Geršič, M. 2017: A comparison of Croatian and Slovenian exonyms. Acta geographica Slovenica 57-1. DOI: https://doi.org/10.3986/AGS.4653

Kladnik, D., Geršič, M. 2014: A gazetteer of Slovenian exonyms. The Quest for Definitions: Proceedings of the $14^{\text {th }}$ UNGEGN Working Group on Exonyms Meeting. Hamburg.

Kladnik, D., Perko, D. 2007: Problematična imena držav v slovenskem jeziku. Geografski vestnik 79-2.

Kladnik, D., Perko, D. 2013a: Slovar slovenskih eksonimov. Zbirka Termania. Medmrežje: http://www.termania.net/ (18. 10.2017).

Kladnik, D., Perko, D. 2013b: Slovenska imena držav. Geografija Slovenije 25. Ljubljana.

Kladnik, D., Perko, D. 2014: Pojasnila k zbirki slovenskih eksonimov. Medmrežje: http://giam2.zrc-sazu.si/ sites/default/files/pojasnila_k_preglednici_z_eksonimi_slo.pdf (16.10.2017).

Kladnik, D., Perko, D. 2015a: Problematika poimenovanja držav in odvisnih ozemelj. Pravopisna razpotja: Razprave o pravopisnih vprašanjih. Ljubljana.

Kladnik, D., Perko, D. 2015b: Družbena občutljivost standardizacije imen držav na primeru Južne Afrike in Moldavije. Pravopisna razpotja: Razprave o pravopisnih vprašanjih. Ljubljana.

Kladnik, D., Pipan, P. 2008: Bay of Piran or Bay of Savudrija? An example of problematic treatment of geographical names. Acta geographica Slovenica 48-1. DOI: https://doi.org/10.3986/AGS48103

Kladnik, D., Pipan, P. 2011: Poimenovanje Piranskega zaliva skozi čas in njegove sodobne medijske razsežnosti. Slovensko-hrvaško sosedstvo. Koper.

Kladnik, D., Pipan, P., Gašperič, P. 2014: Poimenovanja Piranskega zaliva. Geografija Slovenije 27. Ljubljana. Klinar, K. 2013: Projekti zbiranja hišnih in ledinskih imen na Gorenjskem. Dialektološki razgledi 19-2.

Klinar, K., Geršič, M. 2014: Traditional house names as part of cultural heritage. Acta geographica Slovenica 54-2. DOI: https://doi.org/10.3986/AGS54409

Klinar, K., Škofic, J., Šekli, M., Piko-Rustia, M. 2012: Metode zbiranja hišnih in ledinskih imen: projekt FLU-LED v okviru Operativnega programa Slovenija - Avstrija 2007-2013. Jesenice.

Lenarčič, S. 2002a: Čeri v slovenskem pravopisnem morju. Sodobnost 66-1.

Lenarčič, S. 2002b: Čeri v slovenskem pravopisnem morju. Sodobnost 66-3.

Lenarčič, S. 2004: Popravopis - Kaj je narobe in kaj manjka v novem slovenskem pravopisu. Ljubljana.

Lovrenčak, F. 1987: Imena držav in nekaterih drugih upravnih enot. Geografski obzornik 34-1.

Medmrežje 1: https://en.wikipedia.org/wiki/Name_of_the_Czech_Republic (25.11.2017).

Medmrežje 2: https://en.wikipedia.org/wiki/Naypyidaw (27.11.2017).

Medved, J. 1969: O načelih za pisavo tujih geografskih imen. Geografski obzornik 16-2.

Melik, A. 1928: Pisava krajevnih imen. Geografski vestnik 4.

Moder, J. 1972: O pisavi in izreki zemljepisnih imen. Veliki atlas sveta. Ljubljana.

Orel, I. 2003: Zemljepisna imena v slovenskem časopisju do srede 19. stoletja. Besedoslovne lastnosti slovenskega jezika - Slovenska zemljepisna imena. Pišece.

Penko Seidl, N. 2008: Significance of toponyms, with emphasis on field names, for studyng cultural landscape. Acta geographica Slovenica 48-1. DOI: https://doi.org/10.3986/AGS48102

Penko Seidl, N. 2011: Ledinska imena v prostoru in času. Annales, Series historia et sociologia 21-2.

Perko, D. 1995: Komisija za standardizacijo zemljepisnih imen. Geografski obzornik 42-3. 
Perko, D. 1996a: Sporna imena držav v slovenskem jeziku. Geografski obzornik 43-3.

Perko, D. 1996b: Standardizirana imena držav v slovenskem jeziku. Geografski obzornik 43-4.

Perko, D. 2001: Zgoščeni imenik zemljepisnih imen Slovenije. Zbirka državnih imenikov zemljepisnih imen Združenih narodov: Slovenija. Ljubljana.

Perko, D. 2006: Koliko je oceanov? Geografski vestnik 78-2.

Perko, D., Jordan, P., Komac, B. 2017: Exonyms and other geographical names. Acta geographica Slovenica 57-1. DOI: https://doi.org/10.3986/AGS.4891

Perko, D., Kladnik, D. 2017: Slovenian exonyms in North America. Acta geographica Slovenica 57-1. DOI: https://doi.org/10.3986/AGS.4777

Peršolja, B. 2003: Pot zemljepisnega imena od nastanka do uporabe. Geografski vestnik 75-2.

Piko-Rustia, M. 2012: Slovenska ledinska in hišna imena v Unescovem seznamu nesnovne dediščine v Avstriji. Traditiones 21-2. DOI: https://doi.org/10.3986/Traditio2012410216

Pogačnik, A. 2003: Prevzemanje besed v slovenščini. Jezik in slovstvo 48-6.

Pogačnik, A. 2012: Glasovno domačenje lastnih imen iz nelatiničnih pisav. Pravopisna stikanja: Razprave o pravopisnih vprašanjih. Ljubljana.

Preglednica eksonimov 2014. Medmrežje: http://giam.zrc-sazu.si/sl/zbirka/zemljepisna-imena\#v (15. 10.2017).

Radovan, D., Orožen Adamič, M. 1999: Resolucije OZN o zemljepisnih imenih. Delovno gradivo, Inštitut za geodezijo in fotogrametrijo Fakultete za gradbeništvo in geodezijo, Geografski inštitut Antona Melika ZRC SAZU. Ljubljana.

Rotar, J. 1991: Standardizacija zemljepisnih imen. Geodetski vestnik 35-1.

Slovenski pravopis. Ljubljana, 2001.

Snoj, M. 2009: Etimološki slovar slovenskih zemljepisnih imen. Ljubljana.

Snoj, M. 2013: So prebivalci Gruzije »Gruzinci« ali »Gruzijci«? Jezikovna svetovalnica. Medmrežje: http://isjfr.zrc-sazu.si/sl/svetovalnica/kljucne-besede/9783\#v (25.11.2017).

Snoj, M. 2016: Raba predlogov »V« in »na« ob imenih držav. Jezikovna svetovalnica. Medmrežje: https://svetovalnica.zrc-sazu.si/topic/1299/raba-predlogov-v-in-na-ob-imenih-držav (25.11.2017).

Šabec, N. 2003: Raba angleških zemljepisnih imen v slovenščini. Besedoslovne lastnosti slovenskega jezika - Slovenska zemljepisna imena. Pišece.

Šekli, M. 2005: Hišna imena v Ovčji vasi = I nomi in vulgo delle case di Valbruna. Ovčja vas in njena slovenska govorica: raziskovalni tabor Kanalska dolina 2003 = Valbruna e la sua parlata slovena: stage di ricerca Val Canale 2003. Ukve, Ljubljana.

Šekli, M. 2007: Ljudsko zemljepisno izrazje v topoleksemih ledinskega imenja na Livškem. Razvoj slovenskega strokovnega jezika. Ljubljana.

Šivic-Dular, A. 1989: Temeljna načela pri pisanju slovenskih zemljepisnih imen. Jezik in slovstvo 34, 1-2.

Škofic, J. 1998: Mikrotoponimi v Kropi in bližnji okolici. Jezikoslovni zapiski 4.

Škofic, J. 2017. Microtoponyms as an important part of Slovenian cultural heritage. Acta geographica Slovenica 57-1. DOI: https://doi.org/10.3986/AGS.4670

Torkar, S. 2012: Ruska imena ukrajinskih mest. Jezikovna svetovalnica. Medmrežje: http://isjfr.zrc-sazu.si/ sl/svetovalnica/ruska-imena-ukrajinskih-mest\#v (25.11.2017).

Torkar, S. 2015: Moč in nemoč knjižnojezikovnega izročila pri tvorbi etnonimov: k vprašanju Gruzínci ali Grúzijci. Pravopisna razpotja: Razprave o pravopisnih vprašanjih. Ljubljana.

Urbanc, M., Gabrovec, M. 2005: Krajevna imena: poligon za dokazovanje moči in odraz lokalne identitete. Geografski vestnik 77-2.

Vrišer, I. (ur.) 1999: Pokrajine v Sloveniji. Ljubljana.

Weiss, P. 2017: Podomačevanje imen mest: »Konstanz«, »Konstanca«. Jezikovna svetovalnica: Medmrežje: https://svetovalnica.zrc-sazu.si/topic/2266/podomačevanje-imen-mest-konstanz-konstanca (25.11.2017).

Zorko, Z. 2004: Hišna imena na Koroškem: (ob Miklošičevem imenoslovju). Besedotvorje v delih Frana Miklošiča. Maribor. 


\section{Summary: More appropriate use of Slovenian geographical names}

(translated by Drago Perko)

This article is devoted to more complex aspects and examples of the use of Slovenian geographical names, especially exonyms. Proper handling of geographical names is complicated, although many feel that they can easily handle this topic. This is also why in practice there are countless examples of non-systematic and inconsistent use. Nevertheless, the use of geographical names in Slovenian is becoming increasingly uniform. Unification of the use of domestic and foreign geographical names in accordance with the resolutions and recommendations of the United Nations Group of Experts on Geographical Names - represented in Slovenia by the Commission for the Standardization of Geographical Names of the Government of the Republic of Slovenia - is one of the most pressing issues for the modern language norm. International standardization recommendations for writing geographical names are often in conflict with linguistic practice and contrary to the principles of a language, which is completely unacceptable.

This article draws attention to some open issues in the use of currently inconsistent or disputed geographical names in order to contribute to further improvement of the situation in this area. We have encountered disputed and inconsistent names for many years when preparing atlases and maps, editing publications, and participating in shaping the rules for the emerging new Slovenian normative guide (Slovenian Ortography).

The first part of the article presents an extensive and updated overview of engaging with geographical names in Slovenia. A detailed overview of some controversial examples of the use of exonyms for country names follows, as well as a review of disputed and inconsistent use of city exonyms. In order to quantify the subject, we analyzed the frequency of occurrences of geographical names and their variants in the Gigafida language corpus, an electronic collection of authentic Slovenian texts containing almost 1.2 billion words. We also examined the records in the Language Advisory Service of the ZRC SAZU Fran Ramovš Institute of the Slovenian Language and found many detailed records on this topic. The way individual exonyms are represented and recorded in Slovenian reference atlases of the world is presented in an extensive table of exonyms.

It is expected that the new Slovenian normative guide will facilitate the use of geographical names for the general public, especially because of changed rules on using capitalization and international recommendations in more customized rules on the use of foreign lexemes in Slovenian. The names of the most important geographical phenomena are expected to be more systematically presented in the dictionary part of the guide. The materials discussed will also be a good source for the necessary standardization of the bulk of Slovenian geographical names that are still not standardized. 